DRAFT 7/13/2004

\title{
The Dividend Divide in Anglo-American Corporate Taxation
}

\author{
Steven A. Bank ${ }^{*}$
}

\begin{abstract}
Why did the U.S. and U.K. -- two countries with similarly developed economies and corporate cultures -- originally diverge in their approaches to corporate income taxation and why have they continued to vacillate on this issue over time? This Article concludes that it is a result of a divergence in firm dividend policies in the two countries. While firms in both countries maintained liberal dividend policies during the nineteenth century, U.S. firms began to retain more earnings after the turn-of-the-century and this necessitated a change in the method of taxing corporate income. In subsequent years, both countries have undergone major corporate tax reforms during periods of concern about the direction of firm dividend policies in their respective countries. I suggest that this has important implications for predictions about the future of corporate income tax design.
\end{abstract}

There are a variety of approaches to taxing corporations and their shareholders. ${ }^{1}$

On this spectrum of choices, the United States and British corporate income taxes have traditionally stood at opposite ends. The U.S. has what is called a "classical" corporate income tax, ${ }^{2}$ where corporate income is subject to tax at both the corporate level when earned and the shareholder level when distributed as a dividend. ${ }^{3}$ By contrast, the United Kingdom has historically had a shareholder imputation system, where shareholders are

\footnotetext{
* Professor, UCLA School of Law. Previous versions of this paper were presented at the University of Cambridge, where the author was a Herbert Smith Visitor, at the University of Utah, and at the Law and Society Association's 2003 Annual Meeting. Thanks to Reuven Avi-Yonah, Brian Cheffins, Martin Daunton, Boyd Dyer, Victor Fleischer, Peter Harris, Christopher Nicholls, Peter Oh, David Oliver, Kirk Stark, John Tiley, and Manuel Utset for helpful comments. Thanks also to Camille Wooley and Rob Abiri for their research assistance and to Joe Doherty of UCLA School of Law's Empirical Research Group for assisting with the compilation and presentation of the tax and dividend data.

${ }^{1}$ For a sampling of methods from countries around the world, see HUGH J. AULt, Comparative InCOME TAXation: A Structural ANalysis 285 (1997); Peter A. Harris, Corporate/Shareholder InCOME TAXATION 49-72 (1996).

${ }^{2}$ It is not considered "classical" because it is the older or more widely adopted system. In fact, it emerged after the British system and it has never been the predominant system of taxing corporate income. The name appears to relate to the fact that the "classical" view of the corporation is as a separate entity. Thus, any tax that taxes the corporation as a separate entity is viewed as a classical tax.

${ }^{3}$ See I.R.C. §§ 1(h) \& 301.
} 
provided a credit for dividend payments. ${ }^{4}$ Depending upon the size of this credit, it reduces or eliminates the second layer of tax.

This chasm between the two systems, however, has not always existed and both countries have made movements to close the gap at various points during the past century. During the nineteenth century, both the U.S. and the U.K. had a pass-through approach to taxing corporate income. While the U.S. switched to the classical approach in the early twentieth century, integration of the corporate and individual income taxes has been proposed several times, most recently by President George W. Bush in 2003 . This latest effort culminated in a significant reduction in the double tax burden. ${ }^{5}$

Conversely, the U.K. has frequently experimented with a more classical approach, even adopting the U.S. system itself between 1965 and 1973. In 1997, the U.K. all but abandoned the shareholder imputation approach in a move that has nudged its system closer to a classical corporate income tax. ${ }^{6}$

Why did the U.S. and U.K. -- two countries with similarly developed economies and corporate cultures -- diverge in their approaches to corporate income taxation and why do the two countries continue to veer toward and away from each other on this issue? One possible explanation is that the different methods of taxing corporate income are a reflection of the different theories of the corporation. ${ }^{7}$ According to this view, the

\footnotetext{
${ }^{4}$ See HARRIS, supra note 1 , at 770.

${ }^{5}$ See H.R. 2 Jobs and Growth Tax Relief Reconciliation Act of 2003. After budgetary constraints helped to block a provision that would allow shareholders to exclude dividends from income altogether, the final act subjects dividends to capital gain rather than ordinary income rates.

${ }^{6}$ See Reuven Avi-Yonah, Back to the 1930s? The Shaky Case for Exempting Dividends, 97 TAX NOTES 1599 (2002).

${ }^{7}$ See, e.g., Martin Daunton, Just TaXes: The Politics of TaXation in Britain 1914-1979 90 (2002) (suggesting the U.S. system was based upon the theory that the corporation is a real entity and the U.K. system, at least in its earlier form, was premised upon the theory that the corporation was an aggregate of its individual owners); $C f$. Richard M. Hammer, The Taxation of Income from Corporate Shareholders: Review of Present Systems in Canda, France, Germany, Japan, and the U.K., NAT'L TAX J., Sept. 1973, at
} 
U.S. system reflects the notion that the corporation is a real entity, while the U.K.'s suggests the corporation is a mere aggregate of its individual shareholders. Under closer examination, however, entity theory has not proven to be a significant factor in corporate income tax design, at least in the U.S. ${ }^{8}$

This Article concludes that the divide between the U.S. and British corporate tax systems can be explained by a real and perceived divergence in corporate dividend policies. During much of the nineteenth century, corporations in both the U.S. and the U.K. distributed most of their profits as dividends each year and raised capital through the debt or equity markets. ${ }^{9}$ Around the turn-of-the-century, however, a fundamental change in U.S. corporate finance began to occur. Corporations started to retain an increasing percentage of their earnings as an internal method of financing expansion and other needs. ${ }^{10}$ During this same period, no such change occurred in U.K. corporate finance. British corporations were no longer distributing all of their earnings each year as dividends, but they did not follow the lead of U.S. corporations in building up substantial reserves. In fact, British observers reportedly referred to the trend toward increased

315, 323 ("Integration at any level, corporate or shareholder, is based on the same rationale, ie., that a corporation is merely the aggregation of its shareholders and, since under this reasoning the taxation of a corporation and its shareholders cannot be disassociated, the corporation tax is to be viewed, and treated to an extent, as an advance payment of the shareholder's tax."); RICHARD GOODE, THE CORPORATION INCOME TAX 9 (1951) ("The corporation income tax is based on the usual legal view that a corporation and its stockholders are separate persons.").

${ }^{8}$ See Steven A. Bank, Entity Theory as Myth in the Origins of the Corporate Income Tax, 43 Wm. \& Mary L. Rev. 447 (2001) ("Entity Theory Myth").

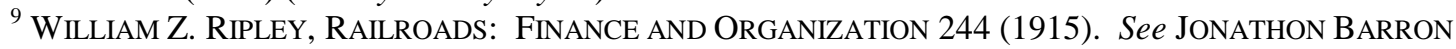
BASKIN \& PAUL J. MIRANTI, JR., A HISTORY OF CORPORATE FINANCE 159 (1997) (“corporate practice reflected a strong preference for debt financing in both the United States and Britain during the nineteenth century, even in the absence of any substantial tax benefits.").

${ }^{10}$ See Steven A. Bank, Is Double Taxation a Scapegoat for Declining Dividends? Evidence from History, 56 TAX L. REV. 463, 480 (2003) ("Scapegoat") (citing Cowles Commission data on retained earnings between 1885 and 1939). 
retained earnings in the U.S. as the "American theory" of corporate finance because it both began in and was originally confined to the States. ${ }^{11}$

This divergence in firm dividend policies had a significant effect on the direction of corporate income taxation in the two countries. During the nineteenth century, when corporations in both countries distributed virtually all of their profits each year, it was reasonable to view a tax on corporations as a mere proxy for taxing shareholders individually on their allocable share of corporate profits. This proxy, which allowed for the collection of the tax at the source, was considered a significant innovation for tax systems suffering under the burden of tax evasion. Not surprisingly, therefore, the United States and the United Kingdom were aligned in their use of a pass-through or integrated approach to corporate income taxation during this period. The U.K., under the Income Tax Act of $1803,{ }^{12}$ and the subsequent Income Tax Act of $1842,{ }^{13}$ integrated the corporate and individual income taxes through an imputation system. Corporations were subject to an income tax. ${ }^{14}$ Shareholders then received a credit for taxes paid on the income at the corporate level and corporations were entitled to deduct from the dividends paid an amount sufficient to cover the corporate-level tax. ${ }^{15}$ In this sense, the corporate

\footnotetext{
${ }^{11}$ See Benjamin Graham \& David L. Dodd, Security Analysis: Principles and Technique 379 (2d ed. 1940).

${ }^{12}$ Income Tax Act, Geo. III, ch. 122, § 127 (1803) (Eng.).

${ }^{13}$ Income Tax Act, 5 \& 6 Vict., ch. 35, § 54 (1842) (Eng.) The Income Tax Act of 1842 was essentially a "reprint" of the 1803 Act with respect to its treatment of corporate income, with only the section numbers changing. I INCOME TAX CODIFICATION COMMITTEE REPORT, Cmd. 51319 (1936) (hereinafter "1936 INCOME TAX CODIFICATION COMMITTEE REPORT").

${ }^{14}$ Corporations were subject to a tax on the "amount of the annual profits, and gains" of the company "before any dividend shall have been" paid. Income Tax Act of 1803, § 127, 44 Stat. 800; Income Tax Act of $1842, \S 54$.

${ }^{15}$ Under section 127 of the 1803 Act, companies were entitled to "a proportionate deduction in respect of the duty so charged." Income Tax Act of $1803, \S 127,44$ Stat. at 801 . While there was no specific exemption from taxation for dividends in the hands of the individual shareholders, the practice was "to regard the dividends paid to shareholders as distributions of profits which had already paid tax in the hands of the company, and the shareholders (like partners) as immune from further taxation in respect of the sums so distributed to them." 1936 InCOME TAX CODIFICATION COMMITTEE REPORT, supra note 13, at 61.
} 
tax operated as a withholding tax for the individual income tax. ${ }^{16}$ In the U.S., the corporate and individual income taxes were also integrated during the nineteenth century, although through different methods. ${ }^{17}$ During the Civil War and Reconstruction, a passthrough approach was employed. There was no separate corporate income tax; instead, shareholders were simply taxed on the undivided profits of the corporation. ${ }^{18}$ When the income tax was revived in the short-lived Tariff Act of $1894,{ }^{19}$ a corporate income tax was imposed and dividends were exempt from the individual income tax.

The increasing conservatism of firm dividend policies in the U.S. necessitated a change in the taxation of corporations soon after the income tax reappeared in $1913 .{ }^{20}$ Initially, the corporate income tax system adopted in the Revenue Act of 1913 -- the first post-Sixteenth Amendment income tax in the U.S. -- was similar to its 1894 predecessor. Because the 1913 Act imposed progressive rather than flat rates, however, the 1894 Act's dividend exemption was not a precise method of integration. Thus, Congress chose to implement its progressive rates by means of a surtax on all income regardless of source. Dividends were exempt from the "normal" tax, but not the surtax. Since the corporate

${ }^{16}$ See HARRIS, supra note 1, at 76. This is considered Lord Addington's "most brilliant" use of the taxation of the source principle, which he introduced as a way to ease the burden of the income tax on individual privacy. SEAn REAmonn, THE PHILOSOPHY OF THE CORPORATE TAX 29 (1970); In his speech introducing the income tax, Addington noted

"[o]ne of the greatest inconveniences which could be attributed to the late Income Tax was, the necessity and hardship it imposed on individuals, in making a full disclosure of the amount of their fortunes. However similar the measure which I am about to propose may be to the tax which I have alluded to, that inconvenience will in this be in a great measure obviated."

A. FARnsworth, AdDington: Author of the Modern Income TaX 52 (1951) (quoting Addington, [Speech delivered to Parliament], THE TIMES, June 14, 1803, at 13).

${ }_{17}$ See generally, Bank, Entity Theory Myth, supra note 8, at 447.

${ }^{18}$ Act of June 30,1864 , ch. $173, \S 117,13$ Stat. 223, 282. In certain industries, corporations were subject to a "dividend tax."

${ }^{19}$ Tariff Act of 1894, ch. 349, 28 Stat. 509.

${ }^{20}$ For a more complete discussion of the gradual move away from the integration scheme, see Bank, Scapegoat, supra note 10 
income tax and normal tax rate were identical, the result was effectively an integrated corporate and shareholder base tax with a surtax overlay. Congress soon realized, however, that it could no longer count on the corporate tax as a mere withholding mechanism for the individual income tax if corporations did not distribute all of their profits each year. This problem worsened as surtax rates rose farther above the corporate income tax rate. ${ }^{21}$ Thus, Congress had to increase the corporate tax as a form of surrogate surtax to recover revenue lost because the profits were not subject to the individual surtax. While the exemption from the individual normal tax for dividends remained for a period of time, the rise in the corporate rate made it an increasingly marginal source of relief for the double taxation of corporate income. ${ }^{22}$ In 1936, the dividend exemption was repealed entirely when Congress adopted an undistributed profits tax. ${ }^{23}$ Corporate income was thus subject to two layers of tax -- the corporate income tax and the individual income tax -- plus the undistributed profits tax if the corporate income was retained prior to distribution. The undistributed profits tax was removed entirely by 1939 , but the dividend tax remained. Corporate managers had little incentive to fight to remove double taxation since its bias against dividends gave them an additional excuse to retain earnings. ${ }^{24}$ The disconnecting of the corporate and individual taxes, as well as the subsequent elimination of the dividend exemption, can be traced to the change in dividend policy among U.S. firms.

\footnotetext{
${ }^{21}$ See infra Figure 3 (comparing the individual surtax and corporate income tax rates between 1913 and 1935).

${ }^{22}$ See supra Figure 4 (comparing the corporate income tax rate and individual normal tax rates between 1913 and 1935).

${ }^{23}$ For a more complete discussion of the events leading up to and following the adoption of an undistributed profits tax in 1936 and the elimination of the dividend exemption, see generally Steven A. Bank, Corporate Managers, Agency Costs, and the Rise of Double Taxation, 44 WM. \& MARY L. REV. 167 (2002) ("Agency Costs").

${ }^{24}$ See id.
} 
Since British firms maintained their more liberal dividend policies, Parliament continued to rely on the shareholder imputation system as its primary method of reaching corporate income. Under the Income Tax Act of 1918, an imputation system similar to the one first adopted in 1803 was employed. ${ }^{25}$ Corporations were subject to an entitylevel income tax, but they were entitled to recover taxes paid at the corporate level by deducting them from dividends paid. Shareholders included the pre-deduction dividend amount in income and then were provided a credit for the taxes paid. This integration system was partially disrupted by a non-creditable profits tax enacted during World War I, ${ }^{26}$ but it was repealed soon after the end of hostilities.

Subsequent efforts to modify the U.S. and British approaches to corporate income taxation have been a reaction to real and perceived developments in dividend policy in the two countries. While the advent of retained earnings prompted the U.S. to separate the corporate and individual income taxes in the first place, the perception of excessive retained earnings has periodically led it to waver from the double tax scheme. In 1936, when President Roosevelt proposed replacing the corporate income tax with an undistributed profits tax and a shareholder-level tax on dividends, the worry was that corporate hoarding was at least partially to blame for the Crash and the ensuing Depression. ${ }^{27}$ More recently, many people blamed Enron and the associated corporate scandals with the reported decline in dividend-paying companies. ${ }^{28}$ The theory was that corporate hoarding led companies to misuse funds. President Bush's proposal to

\footnotetext{
${ }^{25}$ See Income Tax Act of 1918, ch. 40, General Rules Applicable to Schedules A, B, C, D, and E at par. 20.

${ }^{26}$ See HARRIS, supra note 1 , at 89.

${ }^{27}$ See Bank, Agency Costs, supra note 23, at 184-192.

${ }^{28}$ See Jeremy J. Siegel, The Dividend Deficit, WALl ST. J., February 13, 2002, at A20; Edward J. McCaffery, Manager's Journal: Remove a Major Incentive to Cheat, WALL ST. J., July 9, 2002, at B2.
} 
eliminate double taxation was at least partially justified as a method of addressing this concern. $^{29}$

The British experience has been the opposite of that of the U.S. While the U.S. has been concerned with excessive retained earnings, the British focus has been on excessive dividends. In 1947, the differential Profits Tax, sec alled because it differentiated between retained and distributed income by subjecting the latter to a heavier rate of tax, was enacted to encourage corporations to increase their savings and investments after World War II. Part of the concern was that the dividends increased purchasing power and fed post-war inflationary pressures. ${ }^{30}$ After the differential feature in the Profits Tax was dropped in 1958, the British once again became concerned about excessive dividends. In 1965, Parliament abandoned the Profits Tax in favor of a brief experiment with the classical system of double taxation. Through this system, the British hoped to encourage corporations to "plough back" more earnings into the business and thereby jump start investment and the economy. ${ }^{31}$ After repealing the double tax and returning to an imputation system for more than twenty-five years, Parliament once again turned to corporate tax reform in 1997. The stated objective, which was to encourage companies to reinvest profits, echoed the proclamations of earlier reform movements. ${ }^{32}$

Thus, the U.S. and British corporate income tax systems have evolved in response to changes in dividend policy, changes that were motivated at least in part by a number of

\footnotetext{
${ }^{29}$ See Joint Committee on Taxation, Eliminate the Double Taxation of Corporate Earnings ["Bluebook on Integration"], Jan. 2003, at 1 (available at http://www.ustreas.gov/press/releases/docs/bluebook.pdf)

${ }^{30}$ See The Budget, Times (London), Apr. 16, 1947, at 5 (speech of Chancellor of the Exchequer, Hugh Dalton); Morris Beck, British Anti-Inflationary Tax on Distributed Corporate Profits, 1948 NAT'L TAX J. 275.

${ }^{31}$ See Rt. Hon. James Callaghan, The New United Kingdom Tax Structure in Relation to the Needs of the Economy, 5 EUROPEAN TAX'N 212, 215 (1965) (Callaghan was Chancellor of the Exchequer at the time).

${ }^{32}$ See Peter Casson, International Aspects of the U.K. Imputation System of Corporate Taxation, 1998 BRIT. TAX REV. 493 (statement of Chancellor of the Exchequer Gordon Brown).
} 
non-tax related factors. This finding should have important implications for those seeking to unify the corporate income tax systems of these and other countries and for those trying to predict the direction of corporate tax reform. The Article begins in Part I by tracing the transformation from the liberal dividend policy that predominated in both the U.S. and the U.K. during the nineteenth century to a policy of increased retained earnings among U.S. companies around the turn-of-the-century. Part II describes how this change in dividend policy led to a divergence of the corporate income tax in the two countries. Rather than using the corporate income tax as a proxy for a tax on shareholder income, which made sense in an era in which corporations paid out almost all of their earnings as dividends each year, Congress began to focus on the corporation as a separate taxable entity. Since the change in norms regarding dividend policy was an exclusively American phenomenon at the time, the British corporate income tax continued to be a shareholder-focused imputation system. In Part III, the Article discusses how the two corporate income tax systems continue to be driven in large part by real or perceived changes in dividend policy. Finally, the Article briefly concludes by suggesting how these findings might impact corporate income tax reform not just in the U.S. and the U.K, but globally.

\section{The Divergence in Firm Dividend Policies}

During the nineteenth century, dividends flowed freely in both the U.S. and the U.K. According to one observer, "[i]t was the common practice to divide all profits in sight and to finance new construction by the issue of securities. Such policies were fully 
sanctioned by the public opinion of the day. ${ }^{33}$ By the turn-of-the-century, however dividend policies in the U.S. and U.K. began to diverge.

A. U.S. corporations shift to more conservative dividend policies

Corporate finance theory regarding dividends began to change at the end of the nineteenth century, long before the enactment of the income tax in 1913. Whereas the conventional wisdom during much of the nineteenth century had been to distribute all or almost all of a corporation's earnings as dividends and raise expansion capital through the debt or equity markets, by World War I the conventional wisdom was that a corporation should "plow back" a substantial percentage of its earnings to fund expansion, protect against downturns, maintain regular dividend policies, and provide for unexpected expenses. In his 1917 treatise on business finance, William Lough noted that "[i]t is generally agreed that regular dividends combined with large -- or at least adequate -savings out of annual income should be features of the financial management of most corporations." ${ }^{34}$ A few years later, one observer reported that "[t]oday it is taken for granted that no corporation shall pay out more than a fraction of its earnings." ${ }^{35}$

The available data suggests that this change in corporate finance theory was reflected in a change in actual dividend policies. As Figure 1 illustrates, while dividends hovered around 80 to 90 percent of earnings prior to the turn-of-the-century, they had

\footnotetext{
${ }^{33}$ RIPLEY, supra note 9, at 244. See BASKIN \& MIRANTI, JR., supra note 9, at 159 ("corporate practice reflected a strong preference for debt financing in both the United States and Britain during the nineteenth century, even in the absence of any substantial tax benefits."); Ken Brown, So, Will Stock Dividends Get Back Their Respect?, WALl ST. J. ONLINE, Dec. 10, 2002 (quoting Roger Ibbotson, Professor of Finance at Yale)("In the 19th century, it was common practice to pay out everything."); William N. Goetzmann et al., A New Historical Database for the NYSE 1815 to 1925: Performance and Predictability, J. FIN. MGMT 10 (Dec. 2000) (". . this discrepancy between equity yields and bond yields over the course of a decade in our sample period suggests that dividend policy was quite different in the 19th century than it was in the 20th century. The high yields and the fact that many stocks traded near par suggest that most companies paid out a large share of their profits, rather than retaining them.").

${ }^{34}$ WiLLIAM H. LOUGH, BUSINESS FinANCE 477 (1917).
} 
dropped to approximately 50 to 60 percent of earnings during the first decade or so of the twentieth century. ${ }^{36}$

\footnotetext{
${ }^{35}$ Oswald W. Knauth, The Place of Corporate Surplus in the National Income, 18 J. AM. STAT. Ass'N 157, 164 (June 1922).

${ }^{36}$ While the omission of closely held corporations and the inadequacy of nineteenth century financial reporting caution against reading too much into the data, see Bank, Scapegoat, supra note 10at $468-71$, the graph nevertheless highlights that corporate dividend payments dropped during the years preceding the adoption of the modern income tax in 1913.
} 
Figure 1

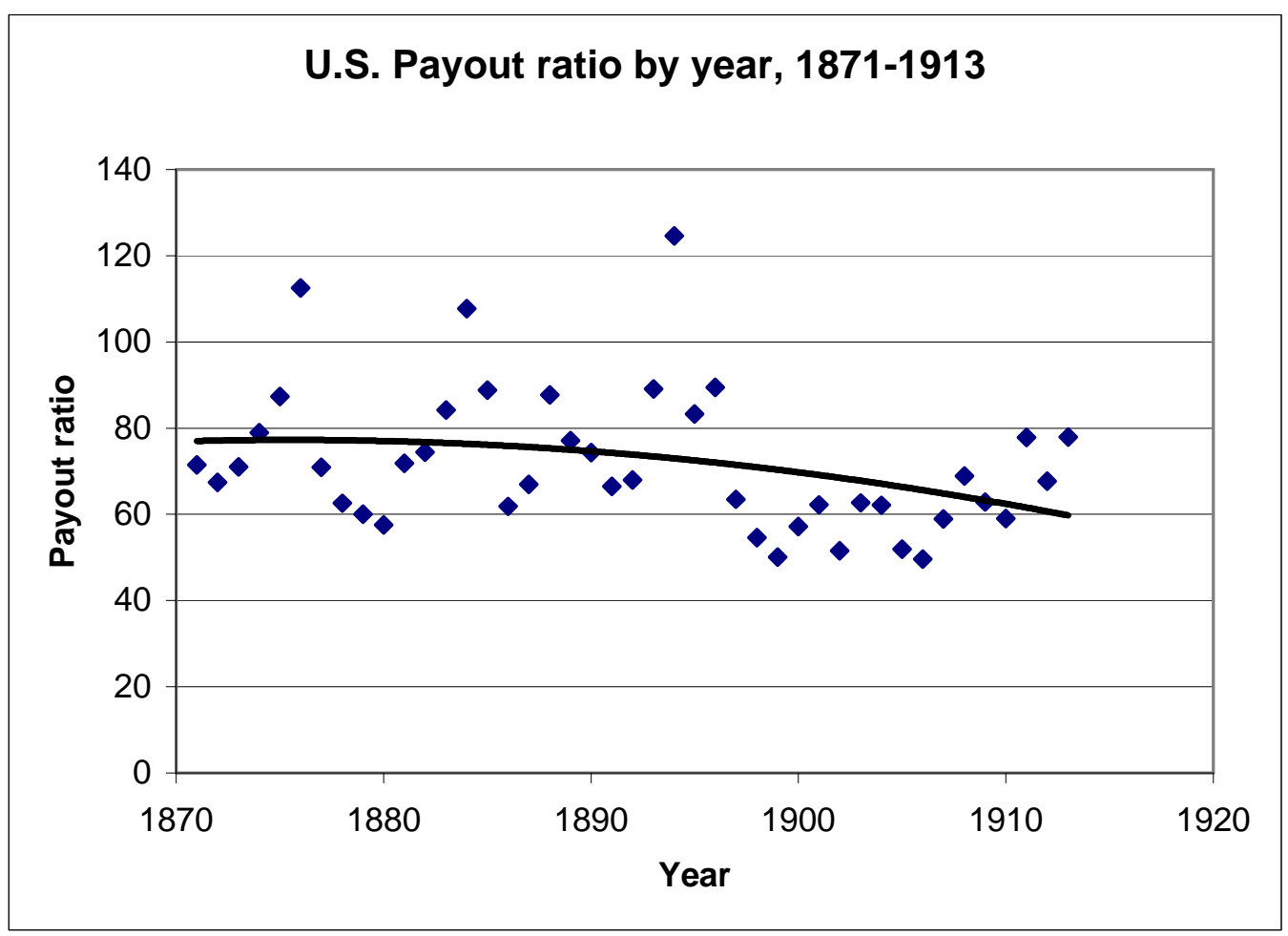

See COWles COMmission fOR RESEARCh IN ECONOMICS, COMMON-STOCK INDEXES 2 ( $2 \mathrm{~d}$ ed., 1939) ("COWLES COMMISSION"); Jack W. Wilson \& Charles P. Jones, An Analysis of the S\&P 500 Index and Cowles's Extensions: Price Indexes and Stock Returns, 1870-1999, 75 J. Bus. 505, 527-531, Appendix: Table A1 (standardizing and updating the data originally compiled by the Cowles Commission for the period 1871 through 1939). "Payout ratio" is defined as the dividends divided by the earnings for the indicated year.

A variety of factors contributed to this shift to a more conservative dividend policy, but the overriding factor was the increasing public ownership, and therefore separation of ownership and control, of corporate enterprise. Prior to the 1880s, most industrial or manufacturing companies other than the large transportation concerns were small, privately held (often by members of the same family), and frequently unincorporated. ${ }^{37}$ Between 1880 and 1930, however, the small, privately held, familycontrolled business gradually gave way to the large, publicly traded, manager-controlled

\footnotetext{
${ }^{37}$ See Walter Werner, Corporation Law in Search of its Future, 81 CoLUM. L. REV. 1611, 1640 (1981); BASKIN \& MIRANTI, supra note 9, at 193.
} 
corporation. ${ }^{38}$ As Adolf Berle and Gardiner Means detailed in their famous 1932 study, ${ }^{39}$

by 1930 a substantial majority of the 200 largest corporations were controlled by

management rather than by an individual or group of individual owners. ${ }^{40}$ Moreover, only four of the 200 largest corporations during this time period did not have publicly traded stock. $^{41}$

This separation of ownership and control had important implications for both manager and stockholder attitudes toward dividend policy. For managers, retaining earnings was the easiest method of financing expansion and thereby increasing their own power and prestige. ${ }^{42}$ Although there are many valid reasons for adopting a more conservative dividend policy, ${ }^{43}$ managers frequently retained earnings at the expense of shareholder interests. ${ }^{44}$ This principal-agent problem was readily apparent to contemporary observers. ${ }^{45}$ As one economist observed in 1933, "[t]he separation of

\footnotetext{
${ }^{38}$ See Werner, supra note 37, at 1641.

${ }^{39}$ See Adolf A. Berle, Jr. \& Gardiner C. Means, The Modern Corporation and Private Property 94 (1932).

${ }^{40}$ Id. Even before Berle and Means published their study, the separation of ownership and control was increasingly evident. William Ripley, writing in 1927, noted that "[t]he prime fact confronting us as a nation is the progressive diffusion of ownership on the one hand and of the ever-increasing concentration of managerial power on the other.” WILLIAM Z. RIPLEY, MAIN STREET AND WALL STREET 131 (1927).

${ }^{41}$ BERLE \& MEANS, supra note 39, at 49.

${ }^{42}$ According to one study of seventy-two public companies during the period from 1922-1930, almost half of the companies financed their growth exclusively with retained earnings and three-fourths used retained earnings for at least 50\% of their financing. O.J. Curry, Utilization of Corporate Profits in Prosperity and Depression, 9 MICH. BUS. STUD. 1, 37 (1941) (noting that some of the companies actually issued stocks and bonds to raise expansion capital for immediate needs, but quickly retired such securities from retained earnings). Moreover, such retentions constituted a significant percentage of the corporation's total assets, with almost half of the companies in the study reinvesting profits equal to 50 percent of the value of the company. Id.

${ }^{43}$ Such reasons might include the inability to access funds through the debt or equity markets on acceptable terms or the need to cushion against downturns.

${ }^{44}$ RIPLEY, supra note 40, at 150 ("for many of the [prospering companies during the Twenties] the rebuilding of the plant from earnings, undertaking very expensive extensions through charges to operation, the accumulation of all sorts of reserves, has gone on seemingly without regard to the right of the present generation of shareholders to the immediate enjoyment of the income of the business.").

${ }^{45}$ For a general discussion of the principal-agent, or agency cost, problem in modern economics and finance literature, see Michael C. Jensen, Agency Costs of Free Cash Flow, Corporate Finance, and Takeovers, 76 Am. ECON. Rev. PAPERS \& PROC. 323, 323 (1986); Frank H. Easterbrook, Two Agency-Cost Explanations of Dividends, 74 AM. ECON. REv. 650, 650 (1984); Eugene F. Fama, Agency Problems and
} 
ownership and management has left the stockholders, i.e., the owners, with hardly any influence on the investment of corporate savings. How is management to overcome the temptation of ploughing earnings back into the institution, even if retrenchment were wiser than expansion?"46 Anotbr observer was even more blunt in his assessment of managers' motives for retained earnings, noting that "the overexpansion of fixed assets, which characterized the latter period [1926-1930], was due in no small measure to the disinclination of directors to relinquish earnings to stockholders; and being disinclined to pay out earnings in dividends, directors sought to reinvest them in the fixed assets of the business. ${ }^{47}$ While the criticism of retained earnings may have been overstated, ${ }^{48}$ there was little doubt that, as one study concluded, "retained earnings resulted more from selfish reasons than from general conservatism." ${ }^{49}$

the Theory of the Firm, 88 J. POL. ECON. 288 (1980); Michael C. Jensen \& William H. Meckling, Theory of the Firm: Managerial Behavior, Agency Costs and Ownership Structure, 3 J. FIN. ECON. 305 (1976). ${ }^{46}$ Robert Weidenhammer, Causes and Repercussions of the Faulty Investment of Corporate Savings, 23 Am. Econ. Rev. 35, 40 (1933). See Norman S. Buchanan, Theory and Practice in Dividend Distribution, 53 Q. J. ECON. 64,81 (1938) ("recently many writers have stressed the growing separation of ownership and control in the large corporation. Under these conditions, one is perhaps unjustified in assuming that dividend policy will be framed with the interests of the shareholders to the fore. Could this possibly explain the tendency to reinvest a large share of the earnings, at least for these corporations?"). Even managers recognized the stakes for this separation of ownership and control. The president of General Motors wrote that "there is a point beyond which diffusion of stock ownership must enfeeble the corporation by depriving it of virile interest in management upon the part of some one man or group of men to whom its success is a matter of personal and vital interest. And conversely at the same point the public interest becomes involved when the public can no longer locate some tangible personality within the ownership which it may hold responsible for the corporation's conduct.” RIPLEY, supra note 40, at 131 (quoting president of G.M.).

${ }^{47}$ ARTHUR StONE DEWING, The FinanCial POLICY OF CORPORATIONs 616-17 (3d ed. 1934).

${ }^{48}$ Arthur Dewing, an early expert in corporate finance, explained that "[t]he simplest and most evident method of obtaining capital to meet the expenditures of an expanding business is through the reinvestment of surplus earnings." Id., at 933-34.

Furthermore, there was ample evidence of companies going bankrupt in part because dividends were too high during a period in which the company should have been creating a cushion out of retained earnings. See HARTLEY WithERS, STOCKS AND SHARES 157 (3d ed. 1938) ("In frequent instances Companies, after paying dividends of fifteen and twenty per cent. for years, have gone into liquidation within twelve months of their last high dividend through their not having in hand a reserve out of which to meet a temporary depression in their particular line of business.").

${ }^{49}$ Curry, supra note 42 , at 8 . See RIPLEY, supra note 40, at 150 ("But there is unquestionably a point beyond which conservatism in the distribution of profits becomes a vice instead of a virtue - particularly when full disclosure of the undistributed profits is denied."); Weidenhammer, supra note 46, at 40 (noting 
Stockholders encouraged managers' push for retained earnings by advocating for regular dividends. For an increasingly distant and more economically diverse group of stockholders, ${ }^{50}$ regular dividends generally were preferable to the wild swings of the typical nineteenth-century company's annual earnings. ${ }^{51}$ Experts advised that such regularity could only be achieved by retaining sufficient earnings in the profitable years to cover the lean years. ${ }^{52}$ Despite the neutral character of such advice, some managers used it as an excuse to retain sufficient earnings retentions to fund their own projects. ${ }^{53}$ As one commentator noted, "[p]robably the first idea was to ensure dividends for the lean years. It is a matter of pride to point to an unbroken dividend record, and annual changes in the rate are not desired by any one; but surpluses are not retained entirely in the liquid form necessary to ensure the fixity of dividends, being often used to increase the fixed assets. ${ }^{54}$ Thus, the demand for more regularity may have served as cover for the more base instincts driving managers to favor a more conservative dividend policy.

B. British companies maintained more generous dividend policies British companies maintained liberal dividend policies long after U.S. firms had switched to policies geared to higher retention of earnings. By 1917, William Lough wrote that "[t]he tendency in European countries is much more strongly in favor of

that many managers chose to reinvest profits in expansion of the business because the size of their own salaries was tied more directly to the size of the business than to the rate of return for stockholders).

${ }^{50}$ Whereas fewer than 4.5 million individuals owned stock in 1900, more than triple that number -- almost 14.5 million -- owned shares by 1922. H.T. Warshow, The Distribution of Corporate Ownership in the United States, 39 Q. J. ECON. 15, 15 (1924).

${ }^{51}$ See Donald E. Wilbur, A Study of the Policy of Dividend Stabilization, 10 HARV. Bus. REV. 373, 373 (1932) ("With the expansion of the stock market and the wide distribution of equities among the American public, new significance has been placed upon the importance of maintaining regular dividends year in and year out.").

${ }_{52}$ LOUGH, supra note 34, at 444 (advising that in order to ensure regularity, "dividends must not be allowed to rise, even in the most prosperous periods, above a conservative estimate of the minimum earnings of the company.").

${ }^{53}$ See GRAHAM \& DODD, supra note 11, at 374-78.

${ }^{54}$ Knauth, supra note 35 , at 164. 
paying out the greater portion of earnings in the form of dividends than it is in the United States." ${ }^{55}$ As Figure 2 demonstrates, during the 1920s, U.K. companies paid out dividends at approximately the same rate -- 80 percent -- as U.S. firms did during the nineteenth century, while U.S. firms were only paying out as dividends approximately 50 to 60 percent of earnings. Stated differently, British companies on average retained approximately 20 percent of their earnings while U.S. companies retained approximately twice as much -- between 40 and 50 percent of earnings. ${ }^{56}$

\footnotetext{
${ }^{55}$ LOUGH, supra note 34, at 439.

${ }^{56}$ Cf. SeRGei P. Dobrovolsky, Corporate InCOME Retention 1915-1943, Appendix C, Table C2, at 110 (1951) (National Bureau of Economic Research study finding retained earnings for U.S. companies in the study averaged approximately $45-50 \%$ during the 1920s); W.A. THOMAS, THE FINANCE OF BRITISH INDUSTRY 1918-1976, Table 4.2, at 89 (1978) (In an analysis of The Economist's compilation of published U.K. company accounts during the period, found retained earnings averaged approximately 20 percent); COLIN ClARK, NATIONAL INCOME AND OUTLAY 186-87 (1937) (noting that during the years 1924-35, the retained earnings of British companies were never as high as $25 \%$ of profits and in many years they were substantibly less) ; A. Wilfred May, American and European Valuation of Equity Capital: A Comparison, 29 AM. ECON. REV. 734, 735, Tbl. 1 (1939) (compilation of U.S. data from 135 corporations during the period 1922-26 and 403 corporations from 1927-29 and British data from 420-459 companies, finding that the U.S. firms retained between 45 and 65 percent and the U.K. firms retained between 70 and 80 percent).
} 
DRAFT 7/13/2004

Figure 2

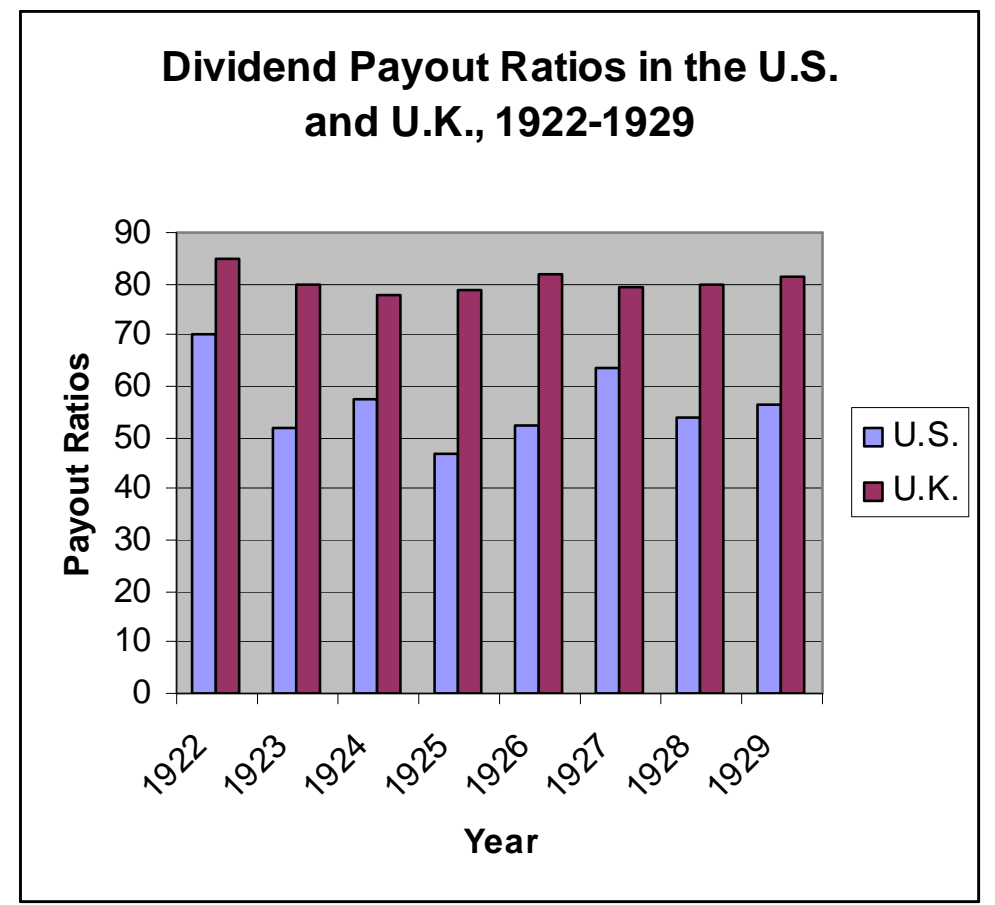

U.S.: Jack W. Wilson \& Charles P. Jones, An Analysis of the S\&P 500 Index and Cowles's Extensions: Price Indexes and Stock Returns, 1870-1999, 75 J. BuS. 505, 527-531 (2002) (Based on data compiled by the Cowles Commission for Research in Economics, Common-Stock Indexes (2d ed. 1939)); U.K.: W.A. THOMAS, THE FINANCE OF BRITISH INDUSTRY 1918-1976 89, tbl 4.2 (1978) (Based on data compiled in The Economist, December 17, 1938, at 600).

This divergence of dividend policies among U.S. and British firms continued throughout the pre-World War II era. In 1940, Benjamin Graham and David Dodd observed the following in their treatise on securities:

It is important to note that this feature [tendency toward high retained earnings] is peculiar to American corporate finance and has no close counterpart in the other important countries. The typical English, French or German company pays out practically all the earnings of each year, except those carried to reserves. Hence they do not build up large profit-and-loss surpluses, such as are common in the United States. Capital for expansion purposes is provided abroad not out of undistributed earnings but through the sale of additional stock. ${ }^{57}$

\footnotetext{
${ }^{57}$ GRAHAM \& DODD, supra note 11 , at 379.
} 
While the British reserves might have been inflated to serve the same purpose as American surplus accounts, ${ }^{58}$ Graham and Dodd note that "these reserve accounts rarely attain a comparable magnitude. ${ }^{.59}$

A variety of factors appeared to conspire to keep down retained earnings among U.K. companies, but the principal factor may be that the trend toward separation of ownership and control occurred later in the U.K. than in the U.S. Whereas Adolf Berle and Gardiner Means noted this phenomenon in U.S. companies in $1932,{ }^{60}$ it was as late as the 1970s before British observers found evidence of a similar development. ${ }^{61}$ This may have had significant effect on the alignment of incentives over dividend policy. In the U.S., managers sought to retain earnings as a method of funding expansion projects that would enhance their own prestige and compensation. ${ }^{62}$ Retained earnings were preferable to securing additional debt or equity because the managers would not be subject to the scrutiny of the capital markets in the use of such funds. In the U.K., the growth of the managerial class was delayed to some extent by the persistence of family control. ${ }^{63}$ Families that retained a significant percentage of the stock in a corporation may have demanded cash distributions to placate those individuals who needed a steady source of income.

Moreover, even where separation of ownership and control had occurred, shareholders maintained a degree of influence over dividends in British corporations that

\footnotetext{
${ }^{58}$ In fact, the British worried about companies' "secret reserve accounts," which could be used to hide profits that were not distributed to shareholders. See Horace B. SAmuel, Shareholders' Money 269 (1933) ("One of the most classic variations of the technique of inflating or deflating profits at the will of the Board is that system of secret reserves which is one of the cornerstones of modern Company finance").

${ }^{59}$ GRAHAM \& DODD, supra note 11 , at 379.

${ }^{60}$ See BERLE, JR. \& MEANS, supra note 39, at 4.

${ }^{61}$ See Brian R. Cheffins, History and the Global Corporate Governance Revolution: The UK Perspective, 43 Bus. HIST. 87, 89-90 (2001).

${ }^{62}$ See supra text accompanying notes $42-49$.
} 
did not exist in the U.S. From early on in the history of British companies, shareholders of most companies were accorded the right to vote on the Board's recommendation to declare a dividend ${ }^{64}$ This right was incorporated in Table A of the U.K.'s Company Acts, ${ }^{65}$ which provided a default rule for companies to adopt in constructing their charters. ${ }^{66}$ While shareholders generally could not vote to change the amount of a Board's recommended dividend and they could not initiate a dividend ${ }^{67}$ they could veto a dividend recommendation. U.S. shareholders have never held even that much power over the dividend decision. The established norm of shared or at least quasi-shared responsibility for the dividend decision in British companies may have perpetuated their high dividend payout ratios, ${ }^{68}$ especially since the depressed profits for British firms during the 1920s made maintaining level dividend payments more difficult. ${ }^{69}$ As Benjamin Graham and David Dodd observed, "the mere fact that the dividend policy is submitted to the stockholders for their specific approval or criticism carries an

\footnotetext{
${ }^{63}$ See Cheffins, supra note 61 , at 90.

${ }^{64}$ According to Professor Colleen Dunlavy's forthcoming database on corporate charters, which describes dividend and other provisions in a series of UK charters adopted between 1845 and 1865, two-thirds of the charters included provisions requiring shareholder approval for declaration of a dividend. For a description of the database, see http://history.wisc.edu/dunlavy/Corporations/c_database.htm.

${ }^{65}$ See IX Companies Act of 1862, Cap. 89, First Schedule, Table A, par.72 (Eng.) ("The Directors may, with the Sanction of the Company in General Meeting, declare a Dividend to be paid to the Members in proportion to their shares.").

${ }^{66}$ For many companies, the articles of association adopted Table $\mathrm{A}$ in toto, including the provision for shareholder vote on dividends, except where specifically excluded or modified. See Fisher v. Black and White Publishing Co., 1901 Law Reports 174 (Ch. 1900).

${ }^{67}$ II Companies Act of 1929, 19 \& 20 Geo. 5, ch. 23, par. 89 (Eng.) ("The company in general meeting may declare dividends, but no dividend shall exceed the amount recommended by the directors."). $C f$. Companies Act of 1985, ch. 6, par. 102 (Eng.) ("Subject to the provisions of the Act, the company may be ordinary resolution declare dividends in accordance with the respective rights of the members, but no dividend shall exceed the amount recommended by the directors.").

${ }^{68}$ See Buchanan, supra note 46, at 83 n.7 ("The tendency to distribute a larger share of the total annual earnings as dividends in Great Britain may, however, be partially explained by the rather common practice of having the shareholders vote upon the question in meeting, rather than leaving the dividends to be determined by the directors as in American corporations.").

${ }^{69}$ See A.J. Arnold, Profitability and Capital Accumulation in British Industry During the Transwar Period, 1913-1924, 52 ECON. HIST. REV. 45, 48 (1999). The vast majority of investors preferred current income rather than capital appreciation. See SAMUEL, supra note 58, at 145 ("Excluding that comparatively small
} 
exceedingly valuable reminder to the management of its responsibilities, and to the owners of their rights, on this important question." 70

The emerging divergence between British and American attitudes toward dividend policy was evident in stockholder disputes. ${ }^{71}$ Railroads were ahead of the curve in the trend toward retained earnings, ${ }^{72}$ perhaps in part because they were also ahead of the curve in the separation of ownership and control, and therefore they were at the center of such disputes. In 1881, for example, the Pennsylvania Railroad Company's relatively conservative dividend policy came under fire. Representatives of a group of British stockholders attended a stockholders meeting "to express their views that all earnings should be distributed to the stockholders and all capital improvements financed by security issues.", 73 According to the company records, "[t]hese efforts continued over a number of years, and as the amount of [British] holding continued to grow, President Roberts and the directors were required to put forth considerable effort to keep the domestic stockholders united in support of the more conservative policy."${ }^{, 74}$

number of persons who buy for capital appreciation, the majority of investors in this country purchase securities in the hope of enjoying the dividends that they anticipate will be paid.").

${ }^{70}$ GRAHAM \& DODD, supra note 11 , at 383 , n. 1 .

${ }^{71}$ This was an important issue because of the increasing degree of British investment in U.S. companies. See BASKIN \& MIRANTI, supra note 9, at 130 (documenting a rise from $\$ 1.1$ billion in 1876 to over $\$ 4$ billion in 1914); HERBERT FEISS, EUROPE: THE WORLD'S BANKER 1870-1914 21 (1930) (noting a resumption of British investment in the U.S. after the Panic of 1893).

${ }^{72}$ See RIPLEY, supra note 9, at 244 ("But a few roads, undoubtedly well in advance of their time, during the '80s began to devote a good part of their earnings to new construction and betterment."); William Z. Ripley, Stock Watering, 26 POL. SCI. Q. 98, 105 (1911) ("Betterments or improvements by the best of our railroads have commonly been in part paid for out of surplus income. Therein lies the great benefit of American over English practice. Dividends have been withheld, sometimes for years, in order to build up a road."). ${ }^{73}$ George H. Burgess \& Miles C. KenNedy, Centennial History OF THE PENNSYlvania Railroad COMPANY 1846-1946 441 (1949). For a general discussion of the advent of British stockholders committees in the American railroad industry, see DOROTHY R. ADLER, BRITISH INVESTMENT IN AMERICAN RAILWAYS 1834-1898 173-74 (Muriel E. Hidy, ed., 1970).

${ }^{74}$ BURGESS \& KENNEDY, supra note 73 , at 441 . See id. at 443 ("The policy of investing a considerable portion of the company's earnings in improvements and extensions of its property was doubtless one reason for the regard in which its securities were held, though this same policy met with great opposition from some of its stockholders, as has been said."). Foreign ownership of the Pennsylania Railroad increased from 7.37 percent in 1871 to 47.46 percent in 1888. See ADLER, supra note 73, at 176, n.30. 


\section{Firm Dividend Policy and the Divergence in Corporate Income Taxation}

In the twentieth century, the U.S. and U.K. approaches to the taxation of corporate income began to diverge. While the U.K. primarily continued the shareholder imputation system that was first adopted in 1803, the U.S. approach soon changed. Because of its concerns about a growing trend toward retained earnings in the U.S., Congress began raising the corporate rate beyond the normal individual rate and otherwise subjecting corporations to what increasingly looked like a separate entity tax. Since British companies did not follow their U.S. counterparts in this change in dividend policy, the U.K. taxation of company income did not need to change from its original approach.

\section{A. U.S.}

The change in corporate finance toward a more conservative dividend policy among U.S. companies was a persistent problem for lawmakers after the ratification of the Sixteenth Amendment. Congress enacted the corporate income tax in 1894 under the assumption that most corporations distributed all or nearly all of their earnings each year as dividends and raised expansion capital through the debt or equity markets. While dividend policies were beginning to change even by then, it was still part of the conventional wisdom for the management of corporate enterprise. Therefore, the quasiwithholding provision view of the corporate income tax was plausible. By 1913, however, when the first post-Sixteenth Amendment revenue act was enacted, the upward trend in retained earnings was clearly noticeable. If the individual income tax had been adopted with a flat rate, this might not have mattered since retentions would be subject to the same rate of tax as distributions. The adoption of progressive individual surtax rates, 
though, meant that the corporate income tax could only serve as an imperfect withholding tax at best for the individual income tax. Congress spent much of the first two decades of the modern income tax battling with corporate managers over this problem of retained earnings.

\section{Revenue Act of 1913}

Upon ratification of the Sixteenth Amendment, ${ }^{75}$ Congress adopted a corporate income tax in conjunction with the individual income tax imposed under the Revenue Act of $1913 .^{76}$ Congress minimized the risk of double taxation, however, by excluding dividends from what was called the "normal" tax on individual income. ${ }^{77}$ Under the 1913 Act, all individual income was subject to a normal, or base, tax levied at a flat rate of one percent. When income reached a certain level, an additional surtax was applied at progressive rates reaching as high as six percent. The corporate income tax rate was explicitly tied to the individual normal tax so that a rise in the normal tax rate would be matched by an identical rise in the corporate tax rate. ${ }^{78}$ By exempting dividends from the normal tax, Congress ensured that corporate and non-corporate income was treated similarly. Corporate income distributed as a dividend was subject to both the one percent corporate income tax and the individual surtax, if applicable, but not to the normal tax, while non-corporate business income was subject to both the one percent normal tax and the surtax, if applicable, but not to the corporate income tax. As a result, the 1913

\footnotetext{
${ }^{75}$ U.S. CONST. amend. XVI.

${ }^{76}$ Tariff Act of 1913, ch. 16, 38 Stat. 114, 166-81.

${ }^{77} \mathrm{Id}$. at $\S \mathrm{II}(\mathrm{B}), 38$ Stat. at $167-68$.

${ }^{78} \mathrm{Id}$. at $\S \mathrm{II}(\mathrm{B}),(\mathrm{G}), 38$ Stat. at 166, 172 ("the normal tax hereinbefore imposed upon individuals likewise shall be levied, assessed, and paid annually upon the entire net income of . . corporations.").
} 
corporate income tax, like its predecessor under the 1894 Act, was a quasi-withholding provision for the individual income tax..$^{79}$

Notwithstanding its use of the quasi-withholding tax structure, Congress was concerned with the trend toward the retention of corporate earnings. As Senator John Sharp Williams, one of the primary Democratic defenders of the income tax bill in the Senate ${ }^{80}$ explained, "it was thought for the purpose of obtaining revenue a corporation might now and then pass up a portion of its profits to surplus or otherwise refrain from distributing them." ${ }^{81}$ The worry was that corporations would become tax avoidance vehicles for high income shareholders because retained earnings were subject to the one percent corporate tax, but not to the surtax until distributed as dividends. ${ }^{82}$ As seen in Figure 3, the gap between the surtax rates and the corporate rates made the corporation a potential vehicle for wealthy taxpayers to park their cash and avoid the higher surtax rates.

\footnotetext{
${ }^{79}$ As with the 1894 version, the 1913 Act did not completely eliminate the double taxation risk because individuals, but not corporations, were entitled to an exemption of $\$ 3,000$ if single or $\$ 4,000$ if married. $I d$., $\S \mathrm{II}(\mathrm{C}), 38$ Stat. at 168 . Thus, for a stockholder whose income fellow below the applicable exemption amount, the corporate income tax subjected them to a tax when they would have had to pay none if the income had come from a non-corporate source. The bill's sponsors rationalized this failure to apply the exemption to corporate stockholders on the grounds that they enjoyed the benefits of investing through the corporate form. See 50 CONG. REC. 509 (1913) (statement of Rep. Cordell Hull). In other discussions of the issue, however, it was clear that part of the obstacle was the administrative difficulties in rebating their share of the tax. See 50 Cong. ReC. 3848 (colloquy between Senators Williams and Cummins).

${ }^{80}$ See Steven A. Bank, Origins of a Flat Tax, 73 DENV. U. L. REV. 329, 393 (1995).

${ }^{81} 50$ CONG. REC. at 3774 (statement of Sen. Williams).

${ }^{82} I d$. at 3775 (statement of Sen. Borah) ("The very difficulty which I presume this amendment was adopted to meet is the fact that they might incorporate, pay the 1 per cent upon their net earnings, and entirely escape the graduated tax or surtax. If there is not some way to meet that, that is precisely what may happen."
} 
Figure 3

\section{U.S. Corporate Tax and Indivividual Surtax Rates, 1913-1935}

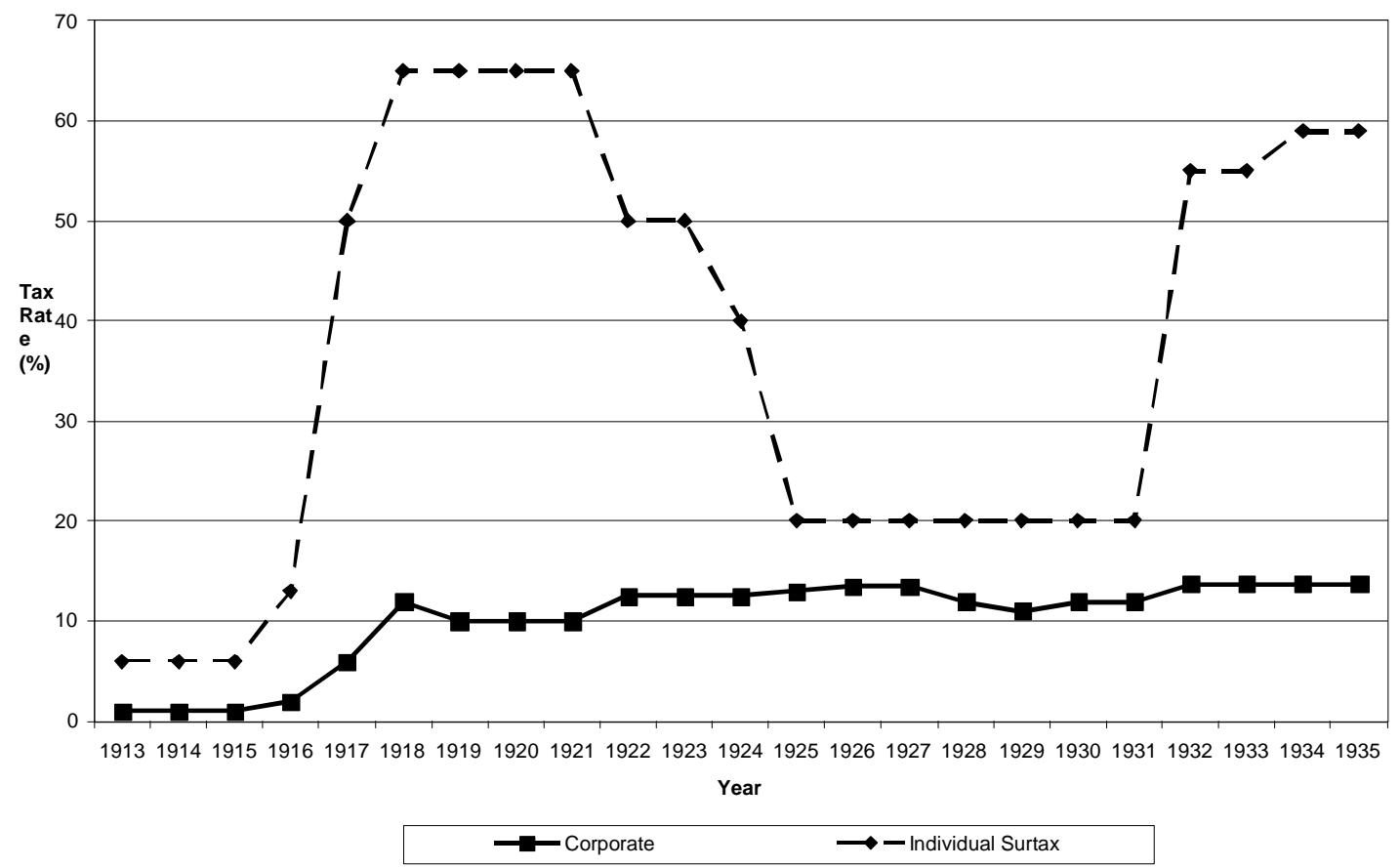

This concern about surtax avoidance prompted the Senate Finance Committee and the

Democratic Caucus to tax individuals on a corporation's undivided profits. An

individual's "taxable income" was defined to include "the share of any taxable individual

of the gains and profits of all companies, whether incorporated or partnership, who would

be legally entitled to enforce the distribution or division of the same, if divided or

distributed, whether divided or distributed or otherwise . . . ${ }^{183}$

\footnotetext{
${ }^{83} 50$ CONG. REC. 3774 (1913) (amendment introduced by Senator Williams). The full text of the amendment is as follows:

For the purpose of this additional tax, taxable income shall embrace the share of any taxable individual of the gains and profits of all companies, whether incorporated or partnership, who would be legally entitled to enforce the distribution or division of the same, if dividend or distributed, whether divided or distributed or otherwise, and any such company, when requested by the Commissioner of Internal Revenue or any district collector of internal revenue, shall forward to him a correct statement of such profits and the names of the individuals who would be entitled to the same if distributed.
} 
Because of its controversial nature, ${ }^{84}$ and because of certain ambiguities, the provision was recommitted to the Senate Finance Committee and a less expansive tax on undistributed earnings was proposed. ${ }^{85}$ Under this revised provision, an additional tax would be imposed only on companies "formed or fraudulently availed of for the purpose of preventing the imposition of such tax through the medium of permitting such gains and profits to accumulate instead of being divided or distributed." ${ }^{86}$ Senator Williams explained that the transformation of the bill was designed to be a more narrowly tailored solution to the problem of tax fraud:

"This clause gave us more trouble than perhaps anything in this bill... . unless we provide for this evil in some way men might escape not the normal tax but escape the additional tax by merely forming themselves, or using a brother, wife, or somebody, or an office boy. Then, while perfectly willing to pay the normal tax as a corporation, they would escape the additional tax by not having their amount distributed by an arrangement so that they could draw upon the corporation, of course, for whatever they needed. ${ }^{87}$

This compromise version was adopted by Congress and is the forerunner for the modern accumulated earnings tax. ${ }^{88}$ The problem of retained earnings generally, however, which the previous version of this provision addressed, continued to loom in the background.

\section{Revenue Act of 1917}

During World War I, it soon became obvious that the real threat to the surtax was not earnings fraudulently retained for the purpose of evading the surtax ${ }^{89}$ but rather

\footnotetext{
Id.

${ }^{84}$ See Attack New Clause as Double Tax, N.Y. TIMES, July 6, 1913, at 5 ("Financial advisers of persons whose incomes are sufficiently large to make them liable for the surtax provided in the income tax bill have called their clients' attention in the last few days to a clause that has been inserted by the Senate Finance Committee and adopted by the Democratic caucus, which has occasioned a good deal of concern and has been criticized as indefensible double taxation.").

${ }^{85}$ See 50 CONG. REC. 3774-75 (1913) (Statement of Sen. Williams) (explaining the intent to recommit the amendment to Committee).

${ }^{86} \mathrm{Id}$. at $4380(1913)$.

${ }^{87}$ Id. at 5318 (1913) (statement of Sen. Williams).
} 
retained earnings generally. According to the sketchy data available to Congress, corporations were retaining an average of at least fifty percent of their earnings each year. ${ }^{90}$ Based on aggregate corporate income amounting to approximately $\$ 9$ billion during the 1917 fiscal year, ${ }^{91}$ Senator Andrieus Jones, a Democrat from New Mexico, argued that this meant that as much as $\$ 450$ million in corporate income was not being subject to the individual surtax rates. ${ }^{92}$ Moreover, as seen in Figure 3 above, with the surtax rates increasing from a high of 13 percent in 1916 to a high of 50 percent in $1917,{ }^{93}$ the magnitude of the lost revenue had increased significantly.

Senator Jones proposed applying an accumulated earnings tax to all undistributed profits, not just those retained for the purpose of evading the surtax rates. Under this proposal, which was originally approved by the Senate Finance Committee and reported out to the Senate, a surtax of 15 percent would be imposed upon undistributed corporate earnings. ${ }^{94}$ Additionally, corporations were granted an exemption equal to 20 percent of earnings, while railroads were entitled to an exemption equal to the amount the Interstate

\footnotetext{
${ }^{88}$ Tariff Act of 1913, ch. 16, § II(A)(2), 38 Stat. 114, 166-67. See I.R.C. § 531 (West 2002).

${ }^{89}$ According to several reports, the accumulated earnings tax was "a dead letter" upon passage. See 55 CONG. REC. 6169 (statement of Sen. Andrieus Jones) ("There is another provision of the law which was intended to prevent corporations from hoarding their earnings for the purpose of avoiding the payment of the surtax by the individual stockholders were the earnings distributed. But the law as it exists has proven a dead letter."); id. at 6172 (statement of Sen. Simmons) ("I think it is generally understood that by reason of the terms of that provision is was not really enforced and it became a dead letter upon the statute books."). Part of the problem was the difficulty in determining when a retention of earnings was in excess of the reasonable needs of the business. Even if Treasury could settle on an appropriate standard for establishing the reasonable requirements of a particular business, Senator Jones explained, this was "a task absolutely impossible of execution, not only as to the varied classes of business of the country but by reason of the enormous task of doing it. You would have to get experts in every line of business." Id. at 6173 (statement of Sen. Jones).

${ }^{90}$ See id. at 6171 (statement of Sen. Jones) (quoting an average of the data from various sources).

${ }^{91} \mathrm{Id}$. at 6167 (statement of Sen. Jones).

${ }^{92} I d$. at 6171 (statement of Sen. Jones).

${ }^{93}$ Compare Revenue Act of 1916, ch. 463, § 1(b), 39 Stat. 756, 757 (imposing a top surtax rate of 13 percent), with War Revenue Act of 1917, ch. 63, § 2, 40 Stat. 300, 301 (imposing a top surtax rate of 50 percent).

${ }^{94} 55$ CONG. REC. at 5966, 6173.
} 
Commerce Commission determined should be retained for the purposes of extensions and improvements. $^{95}$

As with the original 1913 Act provision, the accumulated earnings tax proposal was subject to "widespread criticism." 96 Corporate managers protested that the tax would impede their efforts to expand plant capacity to meet the needs of the war effort, especially in a time when investment capital was limited. ${ }^{97}$ Perhaps most significantly, opponents argued that the trend toward more conservative dividend policies predated the institution of corporate income tax, and, therefore, the notion that all retained earnings were done so to avoid the surtax was false. This argument proved convincing. As Senator Furnifold Simmons, Chairman of the Senate Finance Committee, recounted:

The suggestion had been made that the retention of earnings was for the purpose of escaping and avoiding the income surtaxes, but it was found that before income taxes were imposed by our laws, before there was any possible advantage to be gained from such practice, it was the universal custom and practice. ${ }^{98}$

In response to this firestorm of protest, the undistributed profits tax proposal was rejected in favor of a 10 percent surtax that would exempt all income retained for the reasonable needs of the business. ${ }^{99}$ In effect, Congress simply had retreated to the admittedly unworkable confines of the original accumulated earnings tax.

As an alternative to the undistributed profits tax proposal, Congress chose to raise the corporate income tax rate two percentage points above the individual normal rates in

\footnotetext{
${ }^{95} I d$.

${ }^{96}$ Id. at 6004 (statement of Sen. Penrose).

${ }^{97}$ Id. at 5966 (statement of Sen. Simmons) ("It was pointed out to us that under present conditions, differing so materially from those of the past, it was not only absolutely necessary for them as heretofore to retain a portion of their surplus, but that if they did not do it to a very much larger extent than under ordinary conditions they would be utterly unable to meet the requirements of the present war and emergency situation.”); See Roy G. BlaKey \& Gladys C. BlaKey, ThE FEDERAL InCOME TAX 141 (1940).

9855 CONG. REC. 5966 (1917) (statement of Sen. Simmons).
} 
the War Revenue Act of $1917 .{ }^{100}$ Congress had severed the explicit link between the corporate and normal taxes in the Revenue Act of $1916,{ }^{101}$ but this was a change of form rather than substance since both rates were set at two percent. ${ }^{102}$ As seen in Figure 4, this was the first time the corporate and individual normal tax rates diverged.

Figure 4

\section{U.S. Corporate and Normal Tax Rates, 1913 - 1935}

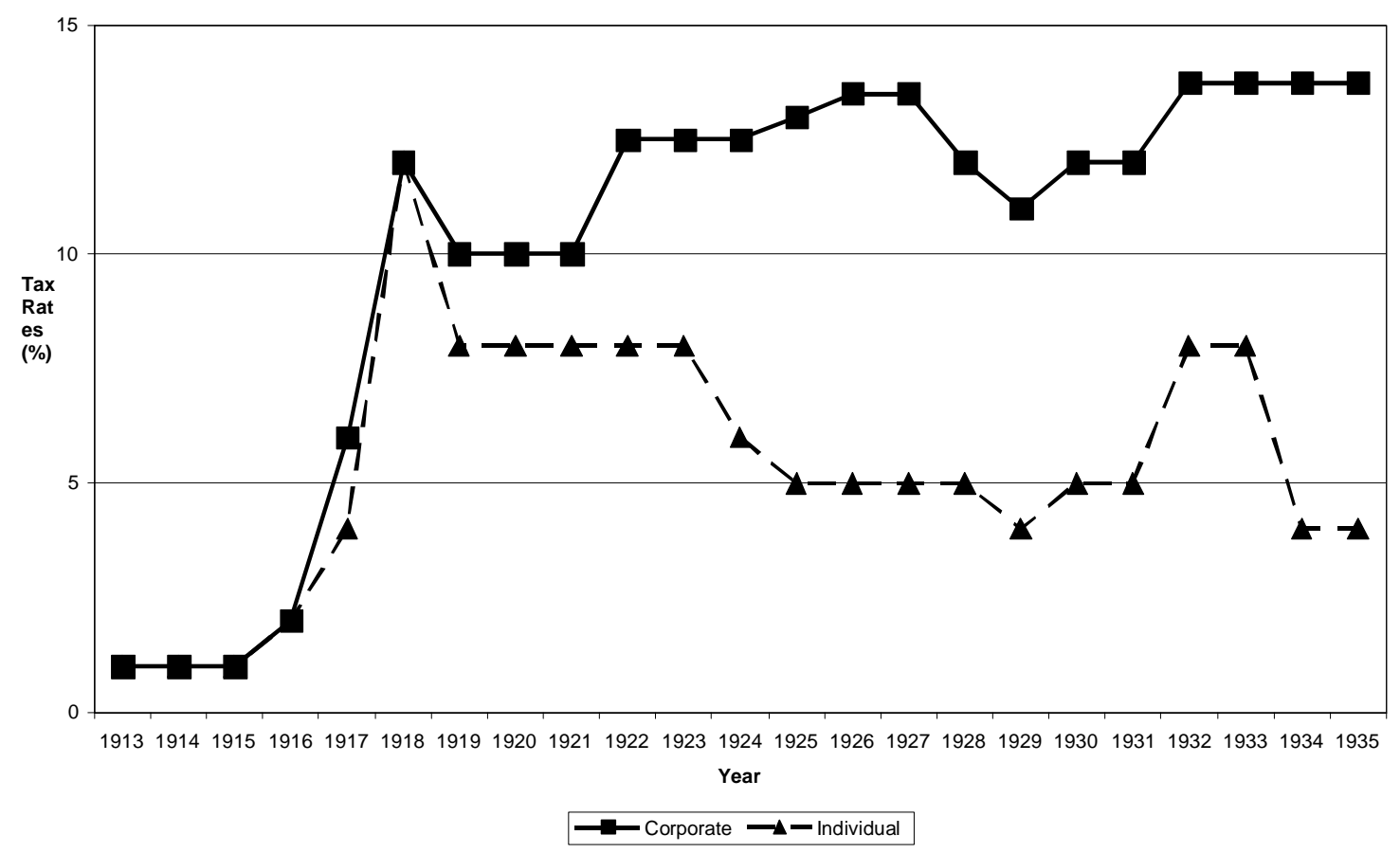

${ }^{99} I d$. at 6004 (statement of Sen. Penrose); Ware Revenue Act of 1917, ch. 63, § 1206, 40 Stat. 300. As in the original version, individuals would be directly subject to the surtax as if they were partners.

${ }^{100}$ See War Revenue Act of 1917, ch. 63, 40 Stat. 300 (enacted October 3, 1917). This was the second revenue measure enacted that year. The Revenue Act of 1917, enacted exactly seven months earlier on March 3, 1917, imposed the first excess profits tax on corporate and partnership income. See SIDNEY RATNER, TAXATION AND DEMOCRACY IN AMERICA 364 (photo. reprint 1980) (1967).

${ }^{101}$ Revenue Act of 1916, ch. 463, 39 Stat. 756 (1916).

${ }^{102} I d$., $\S \S 1,10,39$ Stat. at 756-57, 765-66. As part of an increase in the income tax rates to help meet expenses occasioned by the developing war in Europe, the income tax section was rewritten so as to improve the organization and clarify many of its provisions. See BLAKEY \& BLAKEY, supra note 97, at 120. One byproduct of this rewrite was that the corporate income tax rate was disconnected from the individual income tax rate. Theoretically, this would allow the rates to move independently of each other, although there is no evidence that this was the motivation for the change. 
While an increase in rates was at least partly necessitated by the country's entry into

World War I and President Wilson's desire to pay for the war effort on an ongoing basis rather than through borrowing, ${ }^{103}$ Senator Simmons explained that the divergence between the corporate and individual rates was designed to subject a corporation's retained earnings to a surtax similar in type, if not in degree, to the one applied to individuals:

As it now stands in the corporation income-tax law, and as it has stood from the beginning, the normal tax of the individual and the normal tax, so to speak, of the corporation have been identically the same.... We [increased the corporate income tax rate above the normal tax on individuals] chiefly for the purpose of equalizing any possible difference which might exist between the individual and the corporation with reference to surtaxes. ${ }^{104}$

According to the calculations of Treasury officials, this two percent increase in the corporate income tax rate was expected to raise an additional $\$ 180$ million in revenue. ${ }^{105}$ Senator Simmons noted that this "will very much more than equal the entire surtax if the whole amount had been distributed." ${ }^{106}$ While Senator Jones and others disputed this

\footnotetext{
${ }^{103}$ See BLAKEY \& BLAKEY, supra note 97, at 130.

10455 ConG. ReC. 6172 (1917) (statement of Sen. Simmons). See id. at 6330 (statement of Sen. Smoot) ("the committee undertook to equalize the taxes between the partnership and the corporation by imposing an additional normal tax upon corporations that is not imposed upon partnerships or individuals."); Id. at 5966 (statement of Sen. Simmons) ("Taking all these matters into consideration, your committee decided that the equities of the situation would be best adjusted by imposing a surtax upon such portion of the retained surplus that is not necessary for the reasonable requirements of the business and by making the corporate tax 2 per cent in excess of the normal income tax."). See also S. REP. No. 103, at 12, reprinted in 1939-1 C.B. 56, 68 ("Under both the House bill and existing law the normal tax of the corporation and the normal tax of the individual is the same. In these conditions the earnings of the corporation escape surtax until distributed among its shareholders. This situation seemed to your committee to bring about an inequality between the corporation and the individual which should be remedied as far as practicable.... [Y] our committee believes that the situation would be best met by imposing the surtaxes above mentioned upon such portions of the retained surplus as is not retained for employment in the business and by imposing the additional tax of 2 per cent upon the corporate incomes ...").

10555 CONG. REC. at 6172.

${ }^{106}$ Id. See id. at 6336 (statement of Sen. Simmons) ("The committee thought that if we put upon corporations an additional 2 per cent tax, thereby increasing their income tax $\$ 180,000,000$, it would bring in the first place, into the Treasury four or five times as much money as would come to the Treasury from the surtax upon this 30 per cent or this 20 per cent or this 10 per cent, as the case might be, and that it would leave no injustice as between the corporations and the individuals, because the corporation in its
} 
conclusion, both as to the amount and as to the notion that a flat rate increase would replicate a series of graduated surtax rates ${ }^{107}$ the Finance Committee's logic appeared sufficient to persuade a majority of Congress.

Thus, because of the problem of retained earnings and the imposition of the surtax, Congress had sanctioned the divergence of the corporate and individual income taxes. Some contemporary observers suggested that this development pushed the corporate income tax further away from its original focus on shareholder wealth. ${ }^{108}$ As Fred Taussig noted, because of the divergence "[t]he [corporate income] tax comes even more to be regarded not as one that serves to reach shareholders' income, but one that is to be assimilated to other taxes, to be shifted to the general public, and to leave the shareholder's income undiminished." 109

\section{New Deal and the Undistributed Profits Tax ${ }^{110}$}

The debate over how to tax retained earnings continued to simmer throughout the 1920 s, ${ }^{111}$ but it exploded in the early 1930s. During this period, commentators were consumed with the search for possible causes of the Depression and for methods of

entity dealing with the property of its stockholders would already have paid a much larger amount than the surtax would amount to if they had distribute it.").

${ }^{107}$ Id. at 6174 (statement of Sen. Jones); id. at 6331 (statement of Sen. McCumber)(noting that while the corporation pays six percent and the individual partners in a partnership only four percent for the normal tax, the partners pay an additional thirty percent for the surtax).

${ }^{108}$ See, e.g., F.W. Taussig, The War Tax Act of 1917, Q. J. ECON. 1, 20 (1917); Roy G. Blakey, The War Revenue Act of 1917, 7 AM. ECON. REV. 791, 808-09 (1917).

${ }^{109}$ Taussig, supra note 108, at 20. Although Taussig is correct that the corporate income tax could not be considered to burden shareholders exclusively anymore, if it ever did, the notion that it could ever be wholly shifted to the consumer over the long-term, with little or no impact on capital or labor, is generally rejected. See Jane Gravelle \& Kent Smetters, Who Bears the Burden of the Corporate Tax in the Open Economy, NBER Working Paper Series, No. 8280, at 3 (2001); William A. Klein, The Incidence of the Corporation Income Tax: A Lawyer's View of a Problem in Economics, 1965 WIS. L. REV. 576, 602.

${ }^{110}$ For a more complete discussion of the issues raised in this section, see a companion piece to this article. Steven A. Bank, Tax, Corporate Governance, and Norms (unpublished manuscript, 2004) ("Norms").

${ }^{111}$ See Bank, Scapegoat, supra note 10, at 494-506. 
stabilizing the economy. ${ }^{112}$ One culprit immediately identified was the unreasonable accumulation of corporate profits. According to a memorandum prepared by his advisors during then-Governor Roosevelt's campaign for the Presidency, the prosperity of the Twenties led to "a greater accumulation of surpluses than were ever before realized in economic history." ${ }^{113}$ Rather than distributing such excess profits to stockholders, "corporate administrators have assumed that they were private funds, capable of being withdrawn from personal uses and used to satisfy unrestrained ambitions for expansion."114 This practice of "corporate hoarding," the memorandum charged, "upset the balance of production and consumption" and contributed both to the crash and the ensuing Depression. ${ }^{115}$

Though the memorandum's conclusions may have been suspect, ${ }^{116}$ many shared its view that retained earnings were a serious problem. ${ }^{117}$ During the debates over the

\footnotetext{
${ }^{112}$ See, e.g., Marriner S. Eccles, Controlling Booms and Depressions, in ECONOMIC BALANCE AND A BALANCED BUdGET 69 (Rudolph L. Weissman, ed., 1940); ElEANOR LANSING DULlES, DEPRESSION AND RECONSTRUCTION: A STUDY OF CAUSES AND CONTROLS (1936); LEONARD P. AYRES, THE ECONOMICS OF RECOVERY (1933); PAUl EINZIG, THE WORLD ECONOMIC CRISIS, 1929-1931 (1931); R.T. Ely, Real Estate in the Business Cycle, 22 AM. ECON. REv. 137, 138 (1932); William W. Cumberland, Factors Operating Toward Recovery from Depression, 5 J. OF BUS. OF THE UNIV. OF ChICAGo 114 (1932).

${ }^{113}$ Memorandum of May 19, 1932 of Raymond Moley and others for Franklin Delano Roosevelt outlining national program for recovery in Box 282, Folder 3, Raymond Moley Papers, Hoover Institution Library and Archives, Stanford University. The May 19 memorandum was written in response to a request by Roosevelt to keep him updated during his pre-campaign vacation trip to Warm Springs. The memorandum provided the opportunity to prepare a series of specific recommendations for various aspects of the economic crisis and was the foundation of many of Roosevelt's campaign speeches and eventually his acceptance speech. See Raymond Moley, After SeVen Years 21-22 (1939); DANIEL R. Fusfeld, The ECONOMIC THOUght OF FRANKLIN D. ROOSEVELT AND THE ORIGINS OF THE NEW DEAL 219 (1954). Many, if not most, of the memorandum's recommendations were eventually enacted into law.

${ }_{114}^{114}$ Memorandum of May 19, 1932, supra note 113, at 4.

${ }^{115} I d$. at 2-3. The theory was that profits, which might have been distributed to shareholders or paid to employees and made available for consumption, were instead left idle. To combat the overcapacity problem, companies closed plants and prices rose (because the company had to spread the overhead costs over fewer products) while workers went unemployed and shareholders failed to see a return on their investment. Furthermore, managers' investment of liquid surplus in the market enhanced volatility as managers quickly withdrew money and parked it in short-term securities or in savings accounts. Id.

${ }^{116}$ See Bank, Agency Costs, supra note 23, at 185 n. 85.

${ }^{117}$ Id. at 185, n. 86 .
} 
Revenue Act of 1932, ${ }^{118}$ Representative McFadden went beyond the undistributed profits tax to propose a tax on accumulated surplus itself. ${ }^{119}$ According to McFadden, "[t]hese accumulated profits would have paid taxes to a far greater amount if they had been distributed as dividends when they were earned. If they had been so distributed, we might not have come to the depths in which we find ourselves to-day." ${ }^{120}$ While this proposal received little support, there was substantial concern about retained earnings and the leakage inherent in the accumulated earnings tax. ${ }^{121}$

The post-Crash concern for retained earnings went beyond the tax policy motivations for earlier attempts at an undistributed profits tax. Roosevelt and his advisers were concerned about the misallocation of economic resources. Rex Tugwell, a member of Roosevelt's "Brain Trust" and a Columbia economics professor, ${ }^{122}$ argued that because of managerial control over retained earnings, corporations "grow overconfident of the future and expand their own activities beyond all reason."123 This dovetailed nicely with fellow Brain Truster Adolf Berle's conclusion that because of a growing separation between ownership and control managers increasingly became interested in using retained earnings to fund expansions plans or further their own job security, rather than to support dividends to stockholders. ${ }^{124}$ Tugwell suggested that government needed to "drive corporate surpluses into the open investment market" and out of the hands of

\footnotetext{
${ }^{118}$ Revenue Act of 1932 , ch. 209 , $\S \S 11,47$ Stat. 174. Congress actually cut the gap in half when it raised the individual normal rate from four to eight percent, see id. at $\S 13,47$ Stat. 177, but it soon reversed itself in the Revenue Act of 1934 when the normal tax was reduced to its original four percent. Revenue Act of 1934, ch. 277, §§ 11, 13, 48 Stat. 684, 686.

${ }^{119} 75$ CoNG. REC. 6341 (1932) (statement of Rep. McFadden) (the proposed tax would be 4 percent).

${ }^{120} \mathrm{Id}$.

${ }^{121}$ See, e.g., 75 CONG. REC. 6478 (1932) (statement of Rep. Frear); id. at 6483 (statement of Rep. Blanton).

${ }^{122}$ See FUSFELD, supra note 113, at 207-10. The other key academics in the Brain Trust were Adolf Berle and Raymond Moley. Id.

${ }^{123}$ ReXFORD G. TUGWELl, THE INDUSTRIAL DisCIPLINE AND THE GOVERNMENTAL ARTS 205 (1933).
} 
managers through "a tax ... imposed on funds, over and above replacement, which are kept for expansion purposes." 125 Tugwell and other Brain Trusters had made the same point in the May 19th memorandum to Roosevelt, recommending a "tax on undistributed surplus income of corporations" in order to break the cycle of overproduction and under consumption. ${ }^{126}$ These and other ideas clearly made an impression on Roosevelt. ${ }^{127}$ In his July 1932 acceptance speech at the Democratic national convention, Roosevelt attributed the Depression to heavy "corporate surpluses" used to finance "unnecessary plants" and rampant pre-Crash stock market speculations. ${ }^{128}$

While Roosevelt did not immediately take action against retained earnings upon becoming President, ${ }^{129}$ the undistributed profits tax notion resurfaced a few years later amidst a budgetary crisis. The Supreme Court's striking down of the processing taxes funding the Agricultural Adjustment Act and Congress' overriding of a presidential veto to accelerate payment of bonuses to World War I veterans created two gaping holes in the budget. ${ }^{130}$ Roosevelt turned to the undistributed profits tax to fill the holes. In a

\footnotetext{
${ }^{124}$ BERLE, JR. \& MEANS, supra note 39, at 349-50. For a discussion of this agency cost problem, see supra text accompanying notes 261-66.

${ }^{125}$ TUGWELL, supra note 123, at 206.

${ }^{126}$ Memorandum of May 19, 1932, supra note 113, at 4.

${ }^{127}$ Other rationales forwarded in favor of an undistributed profits tax included the stabilization of the economy and the destruction of monopoly. See John MorTOn Blum, From the Morgenthau DiAries: YEARS OF CRISIS, 1928-1938 307 (1959); Robert H. Jackson, The Proposed Revision of Corporation Taxes, 2 VITAL SPEECHES 431, 432 (1936) (arguing that "antiquated tax laws" permitted corporate managers to use surpluses "to finance monopolistic practices.").

128 July 2, 1932 Speech in I THE PUBLIC PAPERS AND ADDRESSES OF FRANKLIN D. ROOSEVELT 651 (Samuel I. Rosenmann, ed. 1932); ALFRED G. BUEHLER, THE UNDISTRIBUTED PROFITS TAX 18 (1937).

${ }^{129}$ This was in part because Roosevelt was worried that an undistributed profits tax might arouse sufficient opposition to threaten his other New Deal programs. See W. Elliot Brownlee, Historical Perspectives on U.S. Tax Policy Toward the Rich, in Does ATLas SHrug? The ECONOMIC CONSEQuenCES OF TAXING THE RICH 29, 51 (2000).

${ }^{130}$ See United States v. Butler, 297 U.S. 1, 111 (1936) (holding that the Agricultural Adjustment Act "invades the reserved rights of the states. It is a statutory plan to regulate and control agricultural production, a matter beyond the powers delegated to the federal government. The tax, the appropriation of the funds raised and the direction for their disbursement, are but parts of the plan. They are but means to an unconstitutional end."); Revenue Act of 1936: Hearings on H.R. 12395 Before the Sen. Comm. on Fin., $74^{\text {th }}$
} 
supplemental budget message to Congress on March 3, 1936, Roosevelt suggested Congress make up the $\$ 620$ million shortfall by replacing the corporate income tax with an undistributed profits tax. According to Roosevelt, "[a] proper tax on corporate income ... which is not distributed as earned, would correct the serious twofold inequity in our taxes on business profits" by forcing corporations to distribute profits to their shareholders where they would be subject to the same high surtax rates as partnerships and sole proprietorships. ${ }^{131}$ Most significantly, Roosevelt's proposal would completely exempt distributed income from double taxation because the repeal of the corporate income tax would be accompanied by a repeal of the exemption from dividends from the normal tax on individuals. ${ }^{132}$ This would ensure that distributed income would be subject to one layer of tax, but no more than one layer. ${ }^{133}$

Managers soon mounted a fierce opposition to Roosevelt's proposal. While managers had opposed previous attempts to impose an undistributed profits tax during the first decade of the income tax, those proposals generally arose from the concern of one senator - Senator Andrieus Jones - and did not have the support of the Administration or, in most cases, Treasury. Moreover, the emergence of the New Deal and Roosevelt's popularity, achieved to some extent at the expense of business, had raised the stakes. Thus, both directly and through lobbying organizations that they effectively controlled during the period such as the National Association of Manufacturers and the U.S.

Cong., 2d Sess. 2 (1936) ("1936 House Hearings") (statement of Henry Morgenthau, Jr., Secretary of the Treasury) (identifying the two budgetary concerns necessitating the undistributed profits tax proposal).

${ }^{131}$ A Supplemental Budget Message to Congress (March 3, 1936), in 5T HE PUBLIC PAPERS AND ADDRESSES OF FRANKLIN D. ROOSEVELT, supra note 128, at 105.

${ }^{132} I d$. at 106.

${ }^{133}$ Undistributed income would be subject to double taxation because of the application of the undistributed profits tax and the individual normal tax. 
Chamber of Commerce, ${ }^{134}$ corporate managers appeared in force during the hearings in the House Ways and Means Committee on a bill to enact Roosevelt's proposal. ${ }^{135}$ While they claimed to be concerned with the effect of the proposal on small business, ${ }^{136}$ many of their comments suggested that their underlying concern was the potential interference with the decisions of corporate managers and boards of directors. Enacting an undistributed profits tax, G.L. Walters of the Illinois Manufacturing Association complained, would "take from business management one of the most essential matters of management involved in business. Government would just as well take away from all those who have the responsibility of driving automobiles their control over the brakes, the clutch, the throttle, or the steering wheel." ${ }^{137}$ Most seriously, Fred Clausen of the United States Chamber of Commerce worried that the undistributed profits tax "would engender

\footnotetext{
${ }^{134}$ See MARK H. LefF, The Limits OF Symbolic ReForm: The New DeAl AND TAXation, 1933-1939 244 (1984) ("To some extent, this unity [of the business community in opposition to the tax] reflected the dominance of giant corporations in industrial associations."). For instance, while the National Association of Manufacturers nominally represented a broad cross-section of industry, large corporations dominated its decision-making body throughout the New Deal and the World War II period. See Philip H. Burch, Jr., The NAM as an Interest Group, 4 POL. \& SOC'Y 97, 103 (Fall 1973) ("Throughout the New Deal-World War II years and average of about sixty-five to seventy percent of the membership of the executive committee was composed of representatives of big industrial concerns, and in some years eighty percent or more of these important figures was drawn from such select business circles."); Alfred S. Cleveland, NAM: Spokesman for Industry?, HARV. BUS. REV. 353, 365 (May 1948) ("the identity of the inner policy-making group indicates that active leadership within the NAM comes primarily from among the very largest manufacturing corporations"); Richard W. Gable, NAM: Influential Lobby or Kiss of Death?, 15 J. POL. 254, 259, 260 (1953) ("In practice, therefore, the board has constitutionally unlimited power in making all policy decisions. This group has been heavily weighted in favor of an active minority which represents conservative, big businesses and which is an unrepresentative sample of NAM members in terms of size, wealth, and number of employees. . . . Between 1933 and 1937 a total of almost $\$ 4$ million was collected. A group of 262 companies - among th largest and most powerful in the nation - supplied almost 50 per cent of that total."); Richard Walter Gable, A Political Analysis of an Employers' Association: The National Association of Manufacturers 242-43 (1950) (unpublished Ph.D dissertation, University of Chicago) (on file with The University of Chicago library) ("in terms of corporate size and number of employees, the leadership of the Association since 1933 has not been, on the whole, reflective of NAM members, much less of American industry").

${ }^{135}$ While the small, undercapitalized businesses, which were most likely to be affected by the tax, also were active opponents of the bill, corporations with professional managers led the charge.

${ }^{136}$ See 1936 House Hearings, supra note 130, at 352 (statement of G.L. Walters, Illinois Manufacturing Association).

${ }^{137}$ Id. at 339.
} 
such uncertainties concerning the sound course to pursue as to subject the management to grave difficulties with shareholders and creditors." "138

The opposition was unsuccessful as the bill emerged from Committee unscathed and passed in the House with surprisingly little dissent. ${ }^{139}$ Under the bill, the corporate income tax would be replaced by an undistributed profits tax graduated according to the percentage of net income retained. ${ }^{140}$ For corporations with an annual net income of $\$ 10,000$ or less, the rates ranged from $1 \%$ on the first $10 \%$ of undistributed net income to $29.7 \%$ on undistributed net income of $70.3 \%$ or more. ${ }^{141}$ For corporations with annual income in excess of $\$ 10,000$, the bill proposed rates ranging from $4 \%$ on the first $10 \%$ of undistributed net income to a maximum of $42.5 \%$ on undistributed net income of $57.5 \%$ or more. ${ }^{142}$

Republicans changed their strategy in the Senate, choosing both to oppose the undistributed profits tax and to seek to limit its force. To reduce the bill's exclusive reliance on the undistributed profits tax, opponents questioned its revenue-raising ability and harped on its lack of a track record of success. M.L. Seidman of the New York Board of Trade summarized these concerns: "At a time like the present, when the need for revenue is so great, when we are spending so much more than what we are taking on,

\footnotetext{
${ }^{138}$ Id. at 739-40 (statement of Fred H. Clausen, Chairman of the Committee on Federal Finance, Chamber of Commerce of the United States).

${ }^{139}$ See \$803,000,000 Tax Bill Wins by Vote of 267-93 in House; Business Attacks New Deal, N.Y. TIMES, Apr. 30, 1936, at 1. Republican opposition was considered "perfunctory" and the chamber called "indifferent" to their pleas. See Turner Catledge, House Democrats Wind Up Tax Bill; Final Vote Today, N.Y. Times, Apr. 29, 1936, at 1 (calling the proceedings "the most perfunctory witnessed in the House on an important measure in many years."); Editorial, On the Senate's Lap, N.Y. TIMES, Apr. 30, 1936, at 18 ("After little debate worthy of the name, conducted for the most part before an indifferent chamber whose seats were less than one-quarter filled" the House passed the measure). This was due in part to Republican's decision to make "campaign material" out of the tax bill rather than attempt to lessen its impact through amendments. See Republicans Bar Tax Amendments, N.Y. TimES, Apr. 28, 1936, at 12.

${ }^{140} 1936$ House Hearings, supra note 130, at 5.

${ }^{141} I d$. at $5-6$.

${ }^{142} I d$. at 6.
} 
when business is recuperating from the worst depression in our history, and when industry is so sensitive to every disturbing influence, how can we possibly afford to gamble such a vast sum of know public revenue for what is so much an adventure into the wilderness?" 143 These arguments served to reinforce the criticism that the tax was just a thinly veiled attempt to control corporate governance and drive a wedge between managers and their stockholders. ${ }^{144}$

The attack on Treasury's revenue projections proved fatal to the House bill's allor-nothing strategy, but did not defeat the undistributed profits tax altogether. Thus, a group of nine Democrats on the Senate Finance Committee joined the Republican minority to announce an alternate revenue proposal. ${ }^{145}$ Under the proposal, which was prepared with the substantial assistance of the U.S. Chamber of Commerce and its representatives, ${ }^{146}$ the undistributed profits tax would assume a greatly reduced role. In its place, the Senators planned to raise the corporate income tax from the current top rate

${ }^{143}$ Id. at 93 (statement of M.L. Seidman, Chairman, Tax Committee, New York Board of Trade). See Revenue Act of 1936: Hearings on H.R. 12395 Before the Sen. Comm. On Fin., 74th Cong., 2d Sess. 679, 682 (1936) ("1936 Senate Hearings") (statement of James A. Emery, general counsel, National Association of Manufacturers) ("it is not ... a reliable source of revenue, for it is subject to the variations of business policy rather than the net income of the business itself."). See also id. at 220, 221 (statement of Fred H. Clausen, United States Chamber of Commerce) ("The added revenue to be derived is highly uncertain and insufficient. It is less than the budgeted increase in ordinary expenditures for the next fiscal year.").

This theme was also emphasized in the popular press. See, e.g., Taxing and Destroying, Bus. WEEK, May 9, 1936, at 48 ("Nobody knows how much revenue the bill would actually produce; it might be less than the billion dollars obtainable by the present taxes, which the bill would recklessly abolish. ... If the things nobody knows about this bill were laid end to end, they would constitute an aggregate of ignorance as enormous and formidable as American statesmanship has ever been able to boast.”).

${ }^{144}$ Editorial, Punishing Prudence, N.Y. TIMES, March 13, 1936, at 22 ("[i]t has become increasingly obvious that in the eyes of most of its sponsors the proposed tax on corporation surpluses is not primarily a revenue measure, but a new economic 'reform."'); 1936 Senate Hearings, supra note 143, at 520 (statement of Herman H. Lind, National Machine-Tool Builders Association) ("[t]he determination of dividend policy within an individual company will bring to the fore conflicts among various types of stockholders. A very different interest in the amount of earnings to be distributed will be found between stockholders of large incomes and those of small incomes - between those engaged in the management of a business and those who are purely investors."); id. at 722, 724 (statement of H.W. Story, Allis-Chalmers Manufacturing Co.) ("the normal pressure on management by stockholders for the payment of larger dividends" would grow, making it "more difficult for management to pursue a conservative policy of utilizing a large proportion of its earnings for the purpose of promoting the growth of the company."). 
of $15 \%$ to rates ranging from $17.5 \%$ to $20 \%$ and to eliminate the exemption from the normal tax for dividends. ${ }^{147}$ The undistributed profits tax would remain a part of the bill only as a "temporary" tax for three years. ${ }^{148}$

A second proposed alternative emerged that made the tradeoff between double taxation and the undistributed profits tax even starker. Originally set forth in a New York Times editorial, this proposal provided that the existing tax on corporate incomes would be retained, but at a flat rate of $15 \%$ rather than the graduated rates ranging from $12.5 \%$ to $15 \% .{ }^{149}$ In addition, the proposal would eliminate the exemption from the $4 \%$ normal tax on dividends paid to individuals and would impose a $4 \%$ undistributed profits tax. ${ }^{150}$ The identity of rates between the dividend tax and the undistributed profits tax was no mere coincidence. As the Times acknowledged, "[s]uch a tax should raise substantial revenue at the same time as it would be likely to have very little effect on dividend policy, for it would penalize even the relatively low-incomed stockholders no more to retain these profits than to pay them out." ${ }^{151}$ Senator William King, a Democrat from Utah, thought the concept worthy enough that he entered the editorial into the records during the Hearings. ${ }^{152}$

This latter proposal eventually won out in the Senate Finance Committee, although a late push by Committee Chair Pat Harrison helped restore a modicum of

\footnotetext{
${ }^{145}$ See Senate Group Plans Complete Tax Bill Revision, WALL ST. J., May 9, 1936, at 1.

${ }^{146} \mathrm{Id}$. at 2.

${ }^{147} \mathrm{Id}$.

${ }^{148} \mathrm{Id}$.

${ }^{149}$ Editorial, A Compromise Tax Bill, N.Y. TiMES, May 4, 1936, at 18.

${ }^{150} I d$. The American Institute of Accountants simply suggested that the undistributed profits tax be applied at a "low rate." 1936 Senate Hearings, supra note 143, at 603.

${ }^{151} I d$.

${ }^{152}$ See id., at 352 (statement of Sen. King) ("I should like to insert in the record an editorial that the New York Times has in hits morning's issue, a very excellent editorial, and by that I do not mean to give my approval to it in all respects, as to the terms of a bill.").
} 
substance to the undistributed profits tax. As finally passed by the Senate, the undistributed profits tax was set at $7 \%$ and dividends were subject to the $4 \%$ normal tax on individuals. ${ }^{153}$ While business still grumbled about the introduction of even the principle of an undistributed profits tax,${ }^{154}$ they had substantially blunted the plan's distributive pressure. The bill was also a far cry from the $42.5 \%$ rate passed by the House.

In part because of the substantial gap between the House and Senate bills, it was not surprising that the Conference Committee arrived at a compromise satisfactory to no one. As finally adopted, the Revenue Act of 1936 imposed a surtax on the "undistributed net income" of corporations at rates ranging from $7 \%$ to $27 \% .{ }^{155}$ In addition to imposing this surtax on undistributed profits, the 1936 Act retained the normal corporate income tax, with rates ranging from $8 \%$ to $15 \%,{ }^{156}$ and removed the exemption from the $4 \%$ normal individual tax for dividends received. ${ }^{157}$ The result was the imposition of a full two layers of tax on corporate income, in addition to the surtax, whereas income from other sources was only subject to one layer of tax, in addition to the surtax. Because of the increase in the highest undistributed profits tax rate from $7 \%$ in the Senate bill to $27 \%$ in the final Act, however, this additional $4 \%$ normal tax on dividends did not appear to offer much resistance to the push to distribute earnings. The net penalty on retained earnings was still a quite hefty $24 \%$ at the highest marginal rates.

\footnotetext{
${ }^{153}$ See Turner Catledge, 18\% Corporate Income Tax and 7\% on Undivided Profit Agreed on by Senate Group, N.Y. TIMES, May 22, 1936, at 1.

${ }^{154}$ See Turner Catledge, New Tax Program is Held Adequate by the Treasury, N.Y. TIMES, May 17, 1936, at 1, 27 (describing a U.S. Chamber of Commerce statement objecting the proposal).

${ }^{155}$ Revenue Act of 1936, ch. 690, § 14(b), 49 Stat. 1648, 1655.

${ }^{156} I d$. at $\$ 13(\mathrm{~b}), 49$ Stat. at 1655 .

${ }^{157} I d$. at $§ 11,49$ Stat. at 1653 .
} 
Although seemingly one-sided, this compromise was structured so as to minimize the coercive force of the undistributed profits tax. The top rate on the undistributed profits tax was identical to the lowest surtax rate for incomes in excess of $\$ 44,000 .{ }^{158}$ This may have been designed to subject corporate income to the same tax - whether it was retained or distributed - assuming the shareholder's income fell within this surtax bracket. Application of the 4\% normal tax on dividends, therefore, ensured that permitting the corporation to retain profits rather than subjecting them to an additional tax was still logical to that class of shareholders. ${ }^{159}$ Only those shareholders not subject to any surtax - who were presumably the least powerful equity holders - were still likely to clamor for distributions as a result of the ultimately enacted undistributed profits tax.

Double taxation emerged because Congress recognized that undistributed profits avoided the high individual surtax rates and because managers pushed for a solution that would preserve their discretion to retain earnings. After the passage of the Revenue Act of 1936, business opposition to the undistributed profits tax continued. John Morton Blum recounted that, "[b]ecause that tax tended to return to stockholders the decision about how to spend or invest their money, it challenged the power of professional managers of large corporations. These managers, their lawyers, and accountants, in all an able, articulate, and influential group, were aggressive opponents of the tax." ${ }^{, 160}$ Business leaders seized on the recession in the late summer of 1937 as an opportunity to blame the undistributed profits tax for a whole assortment of economic ills. ${ }^{161}$ Eventually, this

\footnotetext{
${ }^{158}$ See Revenue Act of 1935, ch. 829, $§ 101,49$ Stat. 1014 (1935) (both were set at 27\%).

${ }^{159}$ Of course, if the corporation retained the profits and became subject to the tax, the shareholder would eventually be subject to a heavy tax upon distribution. If no distribution was ever made, however, the shareholder could recoup his profits in the form of capital gains upon sale of the stock.

${ }^{160}$ BLUM, supra note 127 , at 321.

${ }^{161}$ Profits Tax Slows Recovery, He Says, N.Y. TIMES, Aug. 28, 1937, at 20 (blamed for decline of retail credit); Levy on Profits Halts Expansion, N.Y. TIMES, Aug. 27, 1937, at 24 (blamed for delay and
} 
proved successful, especially when business began to point to the undistributed profits tax as the principal cause of a crisis in business confidence. ${ }^{162}$ In the Revenue Act of $1938,{ }^{163}$ business leaders once again traded higher corporate rates and double taxation for the nullification of the undistributed profits tax. Thus, the corporate income tax rate was increased to $19 \%$ with a $2.5 \%$ credit available to companies that distributed all of their earnings. ${ }^{164}$ As in the 1936 Act, dividends were subject to the normal tax on individuals. To appease corporate managers who feared that the maintenance of even a symbolic undistributed profits tax would allow it to come back from the dead at a later date, ${ }^{165}$ Congress agreed that the credit for distributed earnings would expire in two years. ${ }^{166}$ Managers made little attempt to revive the dividend exemption after this point, choosing

termination of expansion plans); 15 Criticisms Made of the Profit Tax, N.Y. TIMES, Sept. 26, 1937, at 24 (U.S. Chamber of Commerce study); Surplus Tax Repeal Held Labor Benefit, N.Y. TIMES, Oct. 31, 1937, § III, at 8 (National Association of Manufacturers Study); Editorial, A Tax Theory Demolished, WALL ST. J., Oct. 22, 1937, at 4; Our Taxes Too High, Periling Business, Tremaine Asserts, N.Y. Times, Oct. 1, 1937, at 1 ("[New York State Controller] Tremaine blamed the stock market slump directly upon the Federal Capital Gains and Losses Tax, and the Undistributed Profits Tax."); Ballantine Finds New Deal Harmful, N.Y. TIMES, Oct. 20, 1937, at 10 (highlighting the undistributed profits tax among New Deal programs "as responsible for the current stock market slump").

${ }^{162}$ See Walter Lambert, The New Deal Revenue Acts: The Politics of TaXation 414 (1970).

${ }^{163}$ Revenue Act of 1938, ch. 289, 52 Stat. 447.

${ }^{164}$ Id. at $\S 13(\mathrm{c}), 52$ Stat. at 455. See Business Tax Aids Retained in New Compromise Bill, WALL ST. J., Apr. 23, 1938, at 1; Tax Revision Bill Conferees Adopt Compromise Measure, N.Y. TIMES, Apr. 27, 1938, at 3 .

${ }^{165}$ See, e.g., Revenue Act of 1938: Hearing on H.R. 9682 Before the Sen. Comm. on Finance, $75^{\text {th }}$ Cong., pt. 2183 (1938) (statement of J.W. Hooper, Chairman of the Federal Tax Committee, Brooklyn Chamber of Commerce) (warning that the retention of the undistributed profits tax principle would make it "an everconstant threat); id. at 257 (statement of M.L. Seidman, Chairman of Taxation Committee, New York Board of Trade) ("it would remain to haunt business, not only for what it is, but also for what it may eventually grow into if permitted to remain as a permanent part of our tax structure."); id. at 469 (statement of Ellsworth Alvord, U.S. Chamber of Commerce) ("if you impose 31/2 percent this year . . what is there to assure a businessmen that you will not boost that penalty to $42^{1} \frac{1}{2}$ percent as was proposed two years ago?"). ${ }^{166}$ Modified Surplus Tax for Two Years Retained in Senate-House Compromise, N.Y. TIMES, Apr. 23, 1938, at 1. By this time, even Treasury officials opposed continuing the tax. According to Treasury Secretary Morgenthau, it had become one of the system's "tax irritants." Revenue Revision - 1939: Hearings Before the House Committee on Ways \& Means, $76^{\text {th }}$ Cong., ${ }^{\text {st }}$ Sess. 5 (1939) (statement of Henry Morgenthau, Jr., Secretary of the Treasury). 
instead to focus on a business tax aid program that would increase managers' flexibility and independence. ${ }^{167}$

B. U.K.

Unlike in the U.S., the British corporate income tax did not develop into the classical corporate income tax in the first half of the twentieth century. While there were several wartime measures that imposed a form of economic double taxation on corporate income, they were short-lived and quite unpopular. The underlying impetus for the separation of the corporate and individual income taxes in the U.S. -- retained earnings -did not rise to the same level in the U.K during this period.

1. $\quad 1918$

During World War I, the Income Tax Act of 1842 was consolidated with all succeeding modifications of the system in the Income Tax Act of 1918. ${ }^{168}$ The principle provision governing the taxation of corporate income was contained in General Rule 20. Under this provision, the 1842 version of the corporate income tax scheme was adopted with only mild changes in phrasing. ${ }^{169}$ Thus, the shareholder imputation system survived

\footnotetext{
${ }^{167}$ See Congress Leaders Plan to Expedite Tax Aid Legislation, WALl St. J., May 17, 1939, at 1; Leaders to Push Business Tax Aid at Present Session, WALl St. J., May 16, 1939, at 1. Under this program, business would receive four major tax benefits: (1) Replace the undistributed profits tax and corporate income tax at rates ranging from $16.5 \%$ to $19 \%$ with a flat $18 \%$ corporate income tax; (2) Permit an annual revaluation of capital stock for purposes of the capital stock tax; (3) Eliminate the limit on capital loss deductions for corporations; and (4) Permit corporations to carryforward losses for two or three years. Alfred F. Flynn, Four Point Plan for Tax Revision Being Considered, WALl ST. J., May 13, 1939, at 1. The latter provision was eventually extended to individuals and partnerships in the final House bill. See Two New Concessions to Business Included in House Tax Bill, WALL ST. J., June 17, 1939, at 1; House Passes Tax Revision Bill; Approval by Senate Likely, WALl St. J., June 20, 1939, at 2.

${ }^{168}$ Income Tax Act of 1918, 8 \& 9 Geo. ch. 40.

${ }^{169}$ Id. at General Rule 20:
}

The profits and gains to be charged on any body of persons shall be computed in accordance with the provisions of this Act on the full amount of the same before any dividend thereof is made in respect of any share, right, or title thereto, and the body of persons paying such dividend shall be entitled to deduct the tax appropriate thereto 
the consolidation. Corporations were subject to tax on their income, but to compensate them for paying this tax, they were entitled to deduct from any dividends an amount equal to the proportionate share of the tax paid at the corporate level. Shareholders then received a credit to reflect the fact that tax had already been paid at the corporate level on any dividend income.

The major innovation to the British income tax system between 1842 and 1918 was the introduction of the principle of direct graduation to the income taxes for the year 1909-10. ${ }^{170}$ Under the Finance Act of $1910,{ }^{171}$ a super-tax of 2.5 percent was applied to the regular income tax of just under 6 percent for incomes in excess of $£ 3,000,{ }^{172}$ but not to the withholding at the source scheme. Corporations paid tax at the standard rate and shareholders received a credit against the standard rate for tax paid at the corporate level on dividends. Dividends, however, were still subject to the super-tax in the hands of shareholders when applicable.

Theoretically, the introduction of a progressive super-tax to the British income tax, which was eventually replaced by a surtax, ${ }^{173}$ should have had the same effect on the corporate income tax as it did in the U.S. When income was only subject to a flat rate, a shareholder imputation system assured that it was subject to that rate when earned at the corporate level. Under these circumstances, the decision to distribute profits as dividends was of little consequence to the government. Now that some shareholders were subject

\footnotetext{
${ }^{170}$ The principal of graduation was introduced indirectly starting in 1853 with the use of abatements, but this was found to be impractical for reaching higher incomes without completely exempting lower incomes. See REPORT OF THE RoYAl COMMISSION ON THE INCOME TAX, Cmd. 615 at 28 (1920) (hereinafter "1920 ROYAL COMMISSION").

${ }^{171}$ Finance Act of 1910, § 66.

${ }^{172}$ See 1920 RoYAl Commission, supra note 170, at 123 . The actual percentage for the standard rate on the income tax was $14 \mathrm{~d}$ or 5.83 percent. Id.

${ }^{173}$ See Roswell Magill ET AL., A SUMMARY OF THE BRITISH TAX SySTEM 24-25 (1934) (prepared for the Joint Committee on Internal Revenue Taxation).
} 
to a progressive rate, though, a decision not to distribute profits as a dividend could deprive the government of super-tax revenues.

While this retained earnings problem led the U.S. Congress to raise the corporate rate above the standard individual rate and thereby gradually disconnect the corporate and individual income taxes, ${ }^{174}$ there was no similar reaction in the U.K. Some shareholders did try to avoid the super-tax by arguing that General Rule 20 removed dividend income from the taxable income of the shareholder altogether, but the courts rejected such arguments. ${ }^{175}$ There was no immediate attempt to respond to the potential retained earnings problem via across-the-board legislation along the lines of the U.S. Revenue Act of 1917. The implication is that retained earnings were not yet the significant factor that they had become in America.

\section{Corporation Profits Tax $-1920-24$}

The first sign of a chink in the shareholder imputation system's armor in the U.K. was the adoption of the Corporation Profits Tax in 1920. ${ }^{176}$ Although Parliament had enacted an Excess Profits tax at the onset of World War I in $1915,{ }^{177}$ this levy was applicable to the profits of all business. ${ }^{178}$ When the war ended, however, and the government sought to reclaim the lingering stream of war profits, it limited its focus to corporations. The tax operated as an additional 5 percent tax on corporate income, even

\footnotetext{
${ }^{174}$ See supra Part II.A.

${ }^{175}$ See, e.g., Brooke v. Commissioners of Inland Revenue, 1 K.B. 257, 7 Tax Cases 261 (1918); Whitney v. Commissioners of Inland Revenue, A.C. 37, 10 Tax Cases 88 (1926). Such challenges may have been due in part to the confusion caused by the practice of issuing dividends "free of tax" so that a $£ 10$ dividend, less $£ 3$ deduction for the corporation's income tax would be issued as a $£ 7$ dividend "free of tax." See 1920 Royal Commission, supra note 170, at 39 ("It has also been urged that the system leads to confusion in the taxpayer's mind, because it is frequently difficult to convince him that in making a return of his total income (e.g., for Super-tax purposes) the amount he must show as his income from a 'free of tax' dividend is more than the actual net amount he has received.").

${ }^{176}$ Finance Act of $1920, \S 52$.

${ }^{177}$ Finance (No. 2) Act of 1915, §§ 38-45.
} 
though it was styled as a separate form of tax. ${ }^{179}$ This appeared to be a shift to the American system because it treated the corporation as a separate taxable entity. ${ }^{180}$

Despite the apparent paradigm shift, the corporation profits tax did not signify a true departure from the pass-through nature of the shareholder imputation system. The decision to limit the profits tax to corporations was in part a reaction to the widespread criticism levied against the excess profits duty, which applied to all businesses, and business' preference to it over other alternatives such as a sales tax or a tax on all capital. ${ }^{181}$ It was also easy to justify as remedy for the inequity between corporations and partnerships as to the supertax. ${ }^{182}$ Perhaps to underscore the limited significance of the measure, the Inland Revenue report recommending a corporation profits tax did so under the explicit assumption that the government would soon revert to the former system of taxing corporations. ${ }^{183}$ As soon as the economy recovered sufficiently so as to produce a surplus, the rate was cut in half in 1923 -- to 2.5 percent -- and then repealed the following year. ${ }^{184}$

\section{3. $\quad 1924-1937$}

After the repeal of the corporation profits tax, the British reverted to their prewar scheme. Unlike in the U.S. where the wartime measures only strengthened the growing separation between the corporate and individual income taxes, the British experiment

\footnotetext{
${ }_{178}^{178}$ See HARRIS, supra note 1, at 78 (the rate rose from $15 \%$ in 1915 to $80 \%$ in 1918).

${ }^{179}$ See HARRISON B. SPAULDING, THE INCOME TAX IN GREAT BRITAIN AND THE UNITED STATES 87 (1927).

${ }^{180}$ See DAUNTON, supra note 7, at 89.

${ }^{181} I d$. at $90-92$.

${ }^{182}$ This is based on the same argument raised in the U.S. context. Corporate income was subject to the standard rate when earned and, when distributed, to the supertax. Partnership income was subject to both the standard rate and the supertax when earned, regardless of when the money was distributed. Id. at 91 . ${ }^{183}$ Id. at 91.

${ }^{184}$ Id. at 93. See Finance Act of 1924, § 34.
} 
with the profits tax appeared to have little influence on contemporary views about the taxation of corporate income. ${ }^{185}$ For example, in 1927, one observer wrote

Corporations, except for convenience of collection of the tax, are not treated as taxable entities. The underlying theory is that the income tax is to be imposed only on individuals and in accordance with their taxable capacity.... A corporation is regarded as merely as a device by means of which a number of individuals can conveniently do business, and it is not looked upon as a separate object of taxation. It is not in itself a potentially taxable person, but is an aggregation of persons who may or may not be taxable. It is necessary for some purposes that corporations be regarded as separate legal entities, but the British do not extend this conception to the field of income tax. ${ }^{186}$

By contrast, the fact that U.S. corporations paid tax at a rate higher than the normal rate and shareholders could not recover the difference between the normal and corporate rates was considered a much more significant sign of a separate entity system. ${ }^{187}$

There were some signs that the shareholder imputation system was weakening after the repeal of the Corporation Profits Tax, but these were more akin to minor adjustments than the separation of the corporate and individual income taxes that was occurring in the U.S. For example, in 1927 Parliament clarified one potential ambiguity in the withholding at the source scheme by providing that the corporation's right to deduct from a dividend was based on the corporate tax rate in the year of distribution rather than the corporate tax rate actually imposed on the distributed profits. ${ }^{188}$ Thus, if a corporation paid income tax on its profits at one rate and then distributed those profits in a subsequent year in which a higher rate was in effect, it would withhold from the dividend an amount based on the higher rate even though it had actually paid at the lower

\footnotetext{
${ }^{185} I d$. at 93 ("Corporate taxation did not have a purchase in British fiscal policy, for it contradicted the assumption that firms were agents rather than taxable entities. Corporation taxation did not, as in the United States, connect with hostility to big business or with opposition to a federal income tax.").

${ }^{186}$ SPAULDING, supra note 179 , at 86-87.

${ }^{187}$ See id. at 35.

${ }^{188}$ Finance Act of 1927, § 39.
} 
rate. ${ }^{189}$ While this meant that the deduction was not strictly tied to the amount of tax actually paid, it only enacted what was already imposed in practice on the grounds of administrative simplicity. ${ }^{190}$

British reaction to the U.S. controversy over imposition of an undistributed profits tax in 1936 only confirms the large gulf in the two countries' attitudes toward the corporate tax. Newspapers reported the substantial negative effect the undistributed profits tax appeared to be having on business confidence, ${ }^{191}$ but British business representatives were not entirely sympathetic. The president of the Society of Incorporated Accountants, Walter Holman, observed that "[t]he taxation of undistributed profits seemed particularly hard to Americans who had not previously been subjected to the process of taxing profits at the source, so that the accumulation of undivided profits became increasingly difficult." ${ }^{192}$ Holman suggested that the problem was partly the result of an "inclination to speculation which was part of the makeup of the American temperament." ${ }^{193}$ He explained, "the extension of the taxation of capital profits was a hard blow to a people brought up to invest more for capital increase than for immediate

\footnotetext{
${ }^{189}$ See 1936 InCOME TAX CODIFICATION COMMITTEe RePORT, supra note 13, at 64. While this meant that the corporation could actually profit from the deal by withholding more from than the dividend than was necessary to compensate it for the tax paid on the underlying profits, the converse was also true and corporations would not be made whole if the tax rate dropped between the year tax was paid on the profits and the year in which those profits were distributed as dividends. See H. Arnold Strangman, British and American Taxes, 21 TAXEs 207, 208 (1943).

${ }^{190} I d$.

${ }^{191}$ See, e.g., The Wall Street Slump, TIMES (London), May 4, 1936, at 23 ("The largest single factor perhaps in the change of sentiment reflected in the fall of stock prices has been the proposal, and now the passing by a great majority in the House of Representatives, of the Administration's new Taxation Bill. That Bill . . is regarded generally by Business as an enormous obstacle in the road to recovery."); Heavy Spending in America; Effect of New Tax Law, TIMES (London), Nov. 16, 1936, at 21 ("The endorsement of the 'New Deal' by the electorate at the polls has by no means effected a miraculous reformation in the spirit of corporations. They are quite as desirous as they ever were to conserve their assets and build up comfortable surpluses for a rainy day ..."); President and the U.S. "Slump," TimES (London), Nov. 15, 1937, at 22 ("Revision of that tax [the undistributed profits tax] -- and of the Capital Gains Tax, too, if that were not too much to hope for -- seems to most business men the most hopeful way of curtailing this present depression ...").

192 "Penal" Taxation in the United States, Times (London), Dec. 17, 1937, at 11.
} 
income." ${ }^{194}$ Since the British were used to a relatively free flow of dividends as the primary source of return on their investment, the implication was that the undistributed profits tax would not have produced the same malaise among businesses in the U.K.

Thus, the British maintained the shareholder imputation approach to corporate income taxation as the U.S. was abandoning the dividend exemption in favor of full double taxation. This divergence was a product of the growing divergence in the dividend policies of corporations in the two countries. In the U.K., companies continued to distribute a high percentage of their profits as dividends each year, while in the U.S. the trend toward more retained earnings took hold around the turn-of-the-century, prior to the adoption of an income tax. This difference in corporate finance necessitated a change in approach by U.S. tax authorities and set in motion a sequence of events that led to the adoption of the classical corporate income tax. By contrast, prior to World War II, the U.K. felt no push to alter its traditional shareholder-focused corporate income tax scheme.

III. The Continuing Influence of Firm Dividend Policy on the Evolution of the U.S. and British Systems

During the post-World War II era, there is some evidence that companies in the U.S. and the U.K. have continued to differ on the question of dividend policy. Studies have found that while dividends among U.S. companies dropped to their lowest levels 
ever in the late 1990s, ${ }^{195}$ dividends among British companies rose during the same period. ${ }^{196}$ While there is evidence suggesting that the reverse was true for much of the preceding years, ${ }^{197}$ the more important point is that legislatures in the respective countries perceive that such divergent trends exist and have cited dividend policy as a basis for advocating corporate tax reform. ${ }^{198}$ Thus, in the U.S., there has been a recent push to eliminate the double taxation of corporate income in part to combat the problem of declining dividends. In the U.K., by contrast, there have been several movements toward a more classical corporate double tax system during the last half century because of concern about excessive dividends.

A. U.S.

Although the U.S. has maintained its classical corporate income tax since 1936, concern about excessive retained earnings has helped prompt legislators to revisit this issue. In January of 2003, President Bush announced a proposal to eliminate the double taxation of corporate income. ${ }^{199}$ Under his proposal, income would have been subject to the corporate income tax as under the current regime, but dividends on that income would have been exempt from the shareholder income tax. According to Bush, the goal was to eliminate the double taxation of corporate income.

\footnotetext{
${ }^{195}$ See Jack W. Wilson \& Charles P. Jones, An Analysis of the S\&P 500 Index and Cowles's Extensions: Price Indexes and Stock Returns, 1870-1999, 75 J. Bus. 505, 527-531 (2002) (Appendix: Table A1) (U.S. Dividend Payout Ratio, 1871-2000).

${ }^{196}$ See Stephen Bond et al., Company Dividends and Taxes in the UK, 16 FISCAL STUD. No. 3, 1, 3-5 (1995); Barry Riley, Chemical Reactions, FIN. TIMES, Feb. 27/28, 1993, at II.

${ }^{197}$ See DePartment of Trade AND Industry White PAPER, COMPETITIVENESS: Forging AHEAD, Cmd. 2867, p. 169 (HMSO 1995), available at http://www.archive.official-documents.co.uk/document/dti/dticomp/c13-169.htm (visited July 29, 2003) (suggesting US post-tax net dividend payout ratio far exceeded that of the UK until the early 1990s when they reversed places).

${ }^{198}$ See, e.g., Neil Bennett, City Fears Dorrell's Dividend Designs, LONDON Times, June 6, 1994. (suggesting that a Treasury official's claim that there was a run-up in dividends was partly a misperception of the data).

${ }^{199}$ White House News Release, President Bush Taking Action to Strengthen America's Economy, Jan. 7, 2003.
} 
One significant factor prompting the Bush proposal was the perception that corporations were unnecessarily retaining earnings due to the tax disincentive for dividends and that this was harming the economy. ${ }^{200}$ According to Treasury's Blue Book on Integration, which was released in connection with the Bush announcement, "double taxation of corporate profits encourages a corporation to retain its earnings rather than distribute them in the form of dividends." ${ }^{201}$ Treasury explained that "[t]his lessens the pressure on corporate managers to undertake only the most productive investments because corporate investments funded by retained earnings may receive less scrutiny than investments funded by outside equity or debt financing." ${ }^{202}$ The Council of Economic Advisers concluded that the President's proposal might resolve this issue by increasing the percentage of corporate profits paid out as dividends by as much as four percentage points. ${ }^{203}$

Ultimately, the President's proposal was rejected in favor of more modest double tax relief, but relief nonetheless. Under the Jobs and Growth Tax Reconciliation Act of

\footnotetext{
${ }^{200}$ In the year preceding the release of Bush's proposal, there was a significant outcry in the press and among academics for action in the tax arena to address the issue of declining dividends. See, e.g., James K. Glassman, Numbers You Can Trust, WASH. PosT, Feb. 10, 2002, at H1 ("Unfortunately, dividends are getting more scarce.... Double taxation encourages companies to hold on to most of what they earn, whether the companies really need the money or not."); Siegel, supra note 28, at A20 ("What contributed to the sharp fall in the dividend yield? . . our tax system has played a crucial role."); Amit Ghate, Eliminate Double Taxation of Dividends, CAPITALism Magazine.Com, April 14, 2002; Steve Stein, Taxes, Dividends, and Distortions, POL'Y REV., June-July 2002, at 59; McCaffery, supra note 28, at B2 ("If we repealed the corporate income tax ... [c] orporations would no longer have an excuse for growing large, or an incentive for hiding their gains from everyone to avoid taxation. They could instead pay dividends."); Paul Gompers et al., This Tax Cut Will Pay Dividends, WALl ST. J., Aug. 13, 2002, at A20 ("A the top of his agenda should be the elimination of one of the most detrimental taxes in our economy -- the corporate dividend tax. The sharp decline in cash dividends on common stocks over the past decade has been the major cause of the woes bedeviling the stock market."); Editorial, Bring Back Dividends, WALL ST. J. ONLINE, Aug. 6, 2002 ("There is, however, one big problem with dividends: The government taxes them twice. . Little wonder then that over the past decade or so, as investors become more sensitive to taxes, they start rewarding companies for retaining earnings instead of paying out dividends."); James Glassman, Liberate the Dividend, AM. ENTERPRISE, Sept. 2002, at 13.

${ }^{201}$ See Bluebook on Integration, supra note 29. ${ }^{202} I d$.
} 
2003, "qualified dividend income" is taxed at the same rate as capital gains. ${ }^{204}$ Dividend income is considered qualified if it comes from a taxable domestic corporation and if the recipient has held the corporation's shares upon which the dividend was paid for at least sixty days prior to the ex-dividend date. ${ }^{205}$ When coupled with the reduction of the maximum capital gains rate from 20 to 15 percent, the tax rate on dividends thus was cut by more than half for taxpayers subject to the top individual rates.

While the bill as passed was more modest than the original proposal, it was still justified in part by reference to the retained earnings issue. The House Ways \& Means Committee, in its Report commenting on the final bill, highlighted the concern over retained earnings:

[P]resent law, by taxing dividend income at a higher rate than income from capital gains, encourages corporations to retain earnings rather than to distribute them as taxable dividends. If dividends are discouraged, shareholder may prefer that corporate management retain and reinvest earnings rather than pay out dividends, even if the shareholder might have an alternative use for the funds that could offer a higher rate of return than that earned on the retained earnings. ${ }^{206}$

By placing dividends on the same footing as capital gains, Congress hoped that corporations would not be subject to the pressure to reflect all gains in the stock price, but would instead be encouraged to distribute more dividends.

B. U.K.

While dividend policy has continued to affect corporate tax policy in the U.K. as well, the British have been concerned about excessive dividends rather than excessive retained earnings. There have been three episodes during the post-World War II era

\footnotetext{
${ }^{203}$ See Council of Economic Advisers Briefing Paper on Dividend Tax Cut, 2003 TNT 5-27 (citing a 1992 Treasury study on integration).

${ }^{204}$ I.R.C. $§ 1(\mathrm{~h})(11)$.

${ }^{205} \mathrm{Id}$.

${ }^{206}$ H. REP. NO. 108-94, 108th Cong., 1st Sess. 31 (2003).
} 
where such concern prompted a turn toward a more classical corporate double tax: (1)

Between 1947 and 1958 when British companies were subject to a differential profits tax that levied a high rate on distributions than retentions; (2) Between 1965 and 1973 when Parliament experimented with a classical corporate double tax system; and (3) in 1997 and 1999 when the refundable shareholder dividend tax credit was eliminated and the credit amount was substantially reduced.

1. $\quad 1947-1958$

Parliament continued the shareholder imputation system for taxing corporate income throughout the 1930s, but concerns about dividend policy began to affect tax decisions. In 1937, Parliament imposed a "National Defence Contribution" on profits of all businesses, ${ }^{207}$ although this tax did not single out corporations and was considered a temporary wartime measure. ${ }^{208}$ Soon thereafter, however, Parliament became concerned with the amount of dividends companies were paying in the face of the growing crisis. A proposal to impose a statutory limit on dividends received considerable support until it was dropped in favor of the reenactment of the World War I-era Excess Profits Tax in 1939. ${ }^{209}$

\footnotetext{
${ }^{207}$ Finance Act of 1937, $\S 19-25$.

${ }^{208}$ See 322 PARL. DEB., H.C. (5 ${ }^{\text {th }}$ ser.) 1617 (1937) (statement of Mr. Chamberlain) ("In those circumstances it does not seem to me to be unreasonable to ask that this growth in business profits should be made the occasion of some special and temporary contribution on the part of those concerns which have benefited, towards the cost of National Defence."); The New Excess Profits Tax, TIMES (London), Apr. 21, 1937, at 22 ("This revival of the excess profits duty is, of course, in fulfillment of the Government's undertaking that profiteering shall not be allowed in connection with the rearmament programme."); A. Farnsworth, Some Reflections Upon the Finance Act, 1937, 1 MoD. L. REV. 288, $290-91$ (1938). ${ }^{209}$ Finance (No. 2) Act of 1939, Part III; Business Notes, THE ECONOMIST, Mar. 9, 1946, at 384, 385.
} 
At the end of World War II, dividends became the object of "widespread prejudice." ${ }^{210}$ This was especially true in the Labour Party, where unearned income such as dividends in the hands of shareholders was viewed as an obstacle to egalitarianism and reinvested profits were an acceptable and efficient step toward supply-side economic planning and even nationalized production. ${ }^{211}$ On a more immediate level, there were two complaints about the high level of dividends. First, critics charged that dividends contributed to posł war inflation by increasing consumer spending. ${ }^{212}$ Second, and perhaps more importantly, dividends were viewed as an obstacle to the capital investment necessary to rebuild post-War England. In a speech to Parliament in 1945, Hugh Dalton, the Chancellor of the Exchequer, pleaded with business to cut back on their dividends:

The reduction of the standard rate ... benefits companies as well as individuals, but I hope that the resulting increase in net profits of companies will be spent on new and up-to-date plant and will not go straight into the shareholders' pockets. We cannot afford that right now. In the national interest, capital development must stand in front of high dividends, particularly in the critical next years when we have to convert and modernise at high speed so large a part of our industrial outfit, much of which is badly outmoded. ${ }^{213}$

Soon after this speech, Dalton announced that the Excess Profits Tax would be repealed as of the end of 1946, but the National Defence Contribution would continue as the "Profits Tax." 214 While he did not define the contours of this new Profits Tax, he indicated that it would be determined to some extent by the direction of company

\footnotetext{
${ }^{210}$ Business Notes, supra note 282, at 385. See DAUNTON, supra note 7, at 199 (noting that the prejudice against dividends, but not on the reinvestment of company profits in the business, was part of a Labour "belief that wealth became more reprehensible as it was further removed from its active creation.").

${ }^{211}$ See DAUNTON, supra note 7, at 201-02.

${ }^{212}$ See, e.g., Taxes and Incentives, THE ECONOMIST, Apr. 6, 1946, at 545, 546; 436 PARL. DEB., H.C. $\left(5^{\text {th }}\right.$ ser.) 1122 (1947) (statement of Major Bruce) ("After having pronounced this grave homily on the danger to the nation, they would proceed to add to the inflationary position by declaring an increased dividend for distribution among their shareholders.").

${ }^{213} 414$ PARL. DEB., H.C. (5th ser.) 1896-97 (1945) (statement of Mr. Dalton).

${ }^{214}$ See 421 PARL. DeB. H.C. (5th ser.) 1834 (1946) (statement of Mr. Dalton).
} 
dividend policy. ${ }^{215}$ Dalton reported that industry's response to his invitation to engage in voluntary dividend restraint "has been patchy. Many of the most efficient and up to date concerns have responded very well; but others have shown a tendency to chuck money about among the shareholders, rather than to strengthen their reserves and improve their equipment." 216 He suggested that "it would be premature for me to decide now whether or not, next year, it would be in the general interest to introduce a new tax, designed to check these, as I think, unfortunate practices." 217

Business' apparent failure to heed Dalton's plea against increasing dividends led to the first substantial deviation from the shareholder-focused modelof corporate taxation after the end of World War II. ${ }^{218}$ In 1947, Dalton proposed to modify the Profits Tax so as to levy a heavier burden on distributed than retained earnings. ${ }^{219}$ In introducing this measure, Dalton explained

I cannot pretend to be satisfied with the large increases in distributed profits and the higher dividends which have been paid out in so very many cases in the last 12 months. Too much, in my judgment, has been distributed, and too little ploughed back into the business. These increased dividends are the clearest case, anywhere in our national economy, of an inflationary element. ${ }^{220}$

\footnotetext{
${ }^{215} \mathrm{Id}$

${ }^{216} 421$ PARL. DEB. H.C. (5th ser.) 1833 (1946) (statement of Mr. Dalton).

${ }^{217} \mathrm{Id}$.

${ }^{218}$ Dalton's claim that business had failed to stem the increase in dividends was not uncontroversial. One member cited articles in the Economist and the Times that reported annual figures suggesting that dividend payout ratio and retained earnings percentage numbers were flat). See 436 PARL. DEB., H.C. ( $5^{\text {th }}$ ser.) 1117-18 (1947) (statement of Mr. Assheton) (citing a report in the Economist that companies paid 53.5 percent of profits as dividends in 1945 and 53.2 percent in 1946 and a report in the Times that companies put 24.7 percent of profits into free reserves in 1945 and 25.6 percent in 1946). Others rejected such figures, reporting anecdotal evidence that many large companies had increased their dividend. See 436 PARL. DEB., H.C. ( $5^{\text {th }}$ ser.) 1121 (1947) (statement of Mr. Bruce) ("All I can say is that, of the large number of companies whose results I was examining in the files of "The Times," I could not find one case where there had been a diminution in the dividend last year as compared with the previous year.").

${ }^{219}$ See 436 PARL. DEB., H.C. (5 ${ }^{\text {th }}$ ser.) 84 (1947) (statement of Mr. Dalton).

${ }^{220} I d$.
} 
Under Dalton's proposal, undistributed profits would be subject to the prevailing rate of 5 percent, but distributed profits would be subject to a rate of 12.5 percent. ${ }^{221}$ Soon after its passage, those rates were raised to 10 percent on distributed profits and 25 percent on undistributed profits because of what Dalton called "a continuing and persistent inclination on the part of many concerns to declare increased dividends." 222 The doubling of the rates was said to constitute a "psychologically much greater" inducement to retain earnings, "whatever may be the mathematics of the matter."223 As profits increased and the rate of dividends did not appear to decline, the tax on distributed profits rose dramatically, to 30 percent in 1950 and 50 percent in $1951 .{ }^{224}$ As contemporary observers noted, the British Profits Tax was "in direct contrast" to the Undistributed Profits Tax enacted in the U.S. in $1936 .{ }^{225}$

In 1951, Labour lost control of government and the Conservatives took office with an eye toward reforming the profits tax. The tax on distributed profits was reduced from 50 percent to 22.5 percent and the tax on undistributed profits was lowered from 10

\footnotetext{
${ }^{221} I d$. Only corporations would be subject to this new profits tax scheme, both because individuals and partners were already subject to the individual surtax and because they had only accounted for a small percentage of the revenues from the prior version of the profits tax. Id. at 85.

${ }^{222}$ See 444 PARL. DeB., H.C. ( $5^{\text {th }}$ ser.) 401 (1947) ; Parliament, TimES (London), Nov. 13, 1947, at 6. This may have been prompted in part by some members' calls for higher rates soon after Dalton's proposal was announced. See 436 PARL. DeB., H.C. (5 ${ }^{\text {th }}$ ser.) 1126-27 (1947) (statement of Mr. Beswick) ("I do not think this tax of $12 \frac{1}{2}$ per cent. goes far enough to limit these profits. I have been surprised by the lack of energy with which the Opposition have attacked this Profits Tax. The reason why they have displayed such lack of energy is because, in my view, they were expecting a heavier Profits Tax. I think there was some reason for reducing the 60 per cent. E.P.T., but I do not think there was any reason for reducing it down to $12 \frac{1}{2}$ per cent.").

${ }^{223}$ Profits, Taxes and Dividends, Times (London), Nov. 17, 1947, at 7.

${ }^{224}$ See DAUNTON, supra note 7, at 211 (noting that the 50 percent tax on distributed profits was proposed in conjunction with a statutory limit on dividends, which was never implemented).

${ }^{225}$ Beck, supra note 30, at 275 ("The profits tax of 1947 is specifically designed to encourage retention of earnings, a policy which is in direct contrast to current American and Canadian tax policy aimed at discouraging excessive corporate accumulation."). John Maynard Keynes wrote in 1946 that he objected to the possibility of differential profits taxation in the U.K., pointing out that the surtax creates a bias to under, rather than over-declare dividends, as evidenced by the case of the U.S.: "In the United States this bias has now reached quite extravagant lengths. The New Dealers have tried to devise all sorts of ways of
} 
percent to 2.5 percent. ${ }^{226}$ Even before the transfer of power took place, a Royal Commission on the Taxation of Profits and Income was convened to investigate the effectiveness of the current structure and to recommend changes if necessary. The Commission held hearings on the profits tax and most of the major business trade groups submitted reports and offered testimony.

During the hearings, it became clear that U.K. companies were less concerned with the differential nature of the profits tax as they were with the possibility that it was the proverbial camel's nose under the tent for conversion to a classical corporate income tax. ${ }^{227}$ As the Federation of British Industries (the "Federation") had explained in its original testimony before the Royal Commission, "[a] profits tax is not deductible from a dividend that is paid. ${ }^{2228}$ Thus, unlike with the British income tax, the profits tax could be considered a tax on the company as a separate entity. In 1952, the Federation of British Industries (the "Federation") emphasized this point in its second memorandum to the Royal Commission, stating that "[i]t is the gravamen of the criticism of Profits Tax, that it is a corporate tax which cannot be specifically passed on to shareholders." ${ }^{229}$ When pressed to choose which tax was worse, the one on distributed or retained profits,

encouraging larger declaration of dividends." DAUNTON, supra note 7, at 204 (quoting Keynes, The Dividend Policy of Companies, Mar. 31, 1946, located in Public Records Office, T171/388).

${ }^{226}$ See DAUNTON, supra note 7, at 211.

${ }^{227}$ The business trade groups did not object to the heavier tax on distributions in part because they believed that higher dividends led to demand for higher wages, a claim made by Chancellor of the Exchequer Gaitskell in his 1951 budget message. See A. Rubner, The Irrelevancy of the British Differential Profits

Tax, 74 ECON. J. 347, 352 (1964). The theory, which was controversial even within the Federation of British Industries and National Union of Manufacturers, was that companies needed some external constraint to aid in wage negotiations with unions. Id. Of course, this theory assumed union leaders naively looked to dividends and not gross profits in considering what the company could afford to pay its workers. Id.

${ }^{228}$ Minutes of Evidence taken before the Royal Commission on the Taxation of Profits and Income 84 (Nov. 1, 1951) (testimony of S.P. Chambers, C.D. Hellyar, and A.G. Davies on behalf of the Federation of British Industries).

${ }^{229}$ Federation of British Industries, Second Memorandum to the Royal Commission on the Taxation of Profits and Income 30 (1952). 
the Federation chose the undistributed profits tax in part because it was the most direct example of a separate entity tax. ${ }^{230}$

By the middle of the 1950s, opponents were aided in their cause by the growing sense that the profits tax had done little to effectively stem the tide of dividends or increase the amount of productive investment. ${ }^{231}$ In 1954, one British economist published a report questioning whether the profits tax could actually lower dividends. ${ }^{232}$ The argument was that since British companies had a highly inelastic tendency to distribute dividends regardless of the amount of their profits, a punitive tax on dividends would not lessen the flow of dividends. ${ }^{233}$ Businesses would simply pay the tax by further reducing savings. ${ }^{234}$ This and other reports were apparently sufficient to convince a majority of the Royal Commission that the differential profits tax was no longer worth pursuing as an indirect limit on dividends. In its final report, it concluded that the tax has not prevented the increase in amounts distributed by way of dividend which has been noticeable since 1953, and we are disposed to think that, even with the present big difference between the distributed and undistributed rates, it can only have a minor influence on distribution policy when other influences combine to pull in the opposite direction. ${ }^{235}$

\footnotetext{
${ }^{230}$ Minutes of Evidence taken before the Royal Commission on the Taxation of Profits and Income 84, par. 808 (Nov. 1, 1951) (testimony of S.P. Chambers, C.D. Hellyar, and A.G. Davies on behalf of the Federation of British Industries). After conceding that the undistributed profits tax was the most objectionable, the Federation quickly noted, however, that "every time there is an additional profits tax on distributed profits there appears to be the inference that the payment of dividends is a bad and an improper thing; that, from the point of view of British industry, we regard as unsound." Id. The National Union of Manufacturers also argued against any tax on retained profits, arguing that the company-level tax had curtailed capital investment and cut into, rather than increased, retained earnings available to fund projects. See Tax on Undistributed Profits, Manufacturers' Call for Abolition, TIMES (London), Apr. 2, 1951, at 3.

${ }^{231}$ One business reaction which contributed to this development was the migration of British companies overseas in order to avoid the profits tax. See Arnold A. Rogow, Taxation and "Fair Shares" Under the Labour Government, 21 CANADIAN J. ECON. \& POL. SCI. 204, 213 (1955). Labour even attempted to restrict this migration by inserting a provision in the 1951 Finance Act that made it illegal to migrate overseas if it resulted in evasion of tax liability. Id.

${ }^{232}$ See Rubner, supra note 227, at 353 (citing D. Walker, Some Economic Aspects of the Taxation of Companies, Manchester School, Manchester (Jan. 1954)).

${ }^{233} \mathrm{Id}$.

${ }^{234} \mathrm{Id}$.

${ }^{235}$ Royal Commission on the Taxation of Profits and Income, Final Report, Cmd. 9474, at 159 (June 1955).
} 
When coupled with the fact that there was no evidence that any retained earnings were profitably spent, ${ }^{236}$ and that the differential only served to introduce complexity, ${ }^{237}$ a majority of the Royal Commission recommended ending the differential feature. ${ }^{238}$ Nicholas Kaldor authored a dissent on behalf of himself and two other members of the commission. ${ }^{239}$ They disputed the majority's finding that dividends had not been affected by the differential rates, but conceded that a higher differential might be even more effective. ${ }^{240}$ The minority opposed the repeal of the differential feature unless it was part of a larger reform including the taxation of capital gains. ${ }^{241}$ In a move that foreshadowed developments to come later, Nicholas Kaldor recommended that the U.K. eventually adopt a classical corporate income tax system. ${ }^{242}$

Initially, the minority's views appeared to carry the day. ${ }^{243}$ The then-ruling Conservatives increased the tax on distributed earnings each of the next two years. ${ }^{244}$ When this failed to have the desired effect on dividend policy, however, the

\footnotetext{
${ }^{236} I d$.

${ }^{237} \mathrm{Id}$. at 157.

${ }^{238} I d$. at 159-60 ("The use of differential rates may have been of some value in the immediate post-war years but the argument against such a tax structure increase with the years and in the end must prove decisive. We recommend that the differential rates should be brought to an end.").

${ }^{239}$ See Royal Commission on the Taxation of Profits and Income, Memorandum of Dissent to Final Report, Cmd. 9474, at 354, 382-83 (June 1955) (signed by G. Woodcock, H.L Bullock, and N. Kaldor) (hereinafter "1955 Memorandum of Dissent").

${ }^{240} I d$. at 386 (par. 99) ("The existence of the differential profits tax has undoubtedly been a major cause of the relatively modesty of dividend distributions as compared with the rise of earnings."); id. at 388 (par. 105) ("Nobody would dispute that a differential rate of say, 50 per cent. would not only prevent increased distributions but force companies to reduce the existing level of dividends.").

${ }^{241} I d$. at 388 ("We are strongly opposed therefore to the recommendation of the Majority that the differential profits tax should be abolished forthwith, quite independently of whether capital gains are taxed or not; though we would favour such a change as part of a wider reform which included the taxation of capital gains"). In the U.K., capital gains were not taxed until 1965. See John Tiley,United Kingdom, in COMPARATIVE InCOME TAXATION : A StruCtURAL ANALYSIS 109, 113 (Hugh Ault, ed., 1997).

${ }^{242}$ See 1955 Memorandum of Dissent, supra note 239, at 383-84.

${ }^{243}$ Some suggested that the minority also opposed the differential profits tax, see T. Balogh, Differential Profits Tax, 68 ECON. J. 528 (1958), but this is clearly untrue in at least the short term. See supra note 241.

${ }^{244}$ See Rubner, supra note 227, at 354 (The minority's "prognosis was published in June 1955; in the autumn of the same year the Conservative Chancellor accepted this recommendation of the minority and widened the differential in the profits tax from 1:9 to 1:11.").
} 
Conservatives implicitly declared the experiment with differential rates to be over when it omitted the differential rates from its 1958 budget proposal. ${ }^{245}$ Perhaps sensing that its argument that the rise in dividends would have been greater in the absence of the preferential rates lacked rhetorical force, "the Labour Party did not mount a concerted attack" against this omission. ${ }^{246}$

\section{2. $1965-1973$}

Not long after the repeal of the differential feature of the profits tax, the government once again became concerned with the dividends and industrial investment. ${ }^{247}$ In his budget statement to Parliament in November of 1964, James Callaghan, Labour's newly-appointed Chancellor of the Exchequer, expressed concern with the current system. According to Callaghan, the corporate income tax system "does not provide sufficient incentive to companies to plough back profits for growth rather than to distribute them as dividends." 248 While the government had enacted a generous set of depreciation deductions in 1954 with the goal of increasing investment, Callaghan believed that they were insufficient by themselves to make a difference. ${ }^{249}$

To further increase the incentive for corporations to retain earnings, Callaghan proposed reforming the tax system. Rather than returning to the 1950s differential profits tax feature, however, Callaghan advocated repealing the profits tax and the adoption of

\footnotetext{
245 Id.

${ }^{246} \mathrm{Id}$

${ }^{247}$ According to one account, "[w] hen the differentiated Profits Tax was abolished in 1958, and tax incentive for retentions was removed, there was an immediate upsurge in distributions, and that has continued to the present day." 712 PARL. DEB., H.C. (5th ser.) 52 (1965) (statement of Mr. Niall MacDermot). See 713 PARL. DEB., H.C. $\left(5^{\text {th }}\right.$ ser.) 1834 (1965) (statement of Chief Secretary to the Treasury, John Diamond) ("Previously we had a system which encouraged retention and that was replaced by a single-tier Profits Tax which removed that encouragement to retention. Therefore, there was further distribution, and the rate of growth of dividends went up by 50 per cent. as a result.").

248701 PARL. DEB., H.C. (5th ser.) 1041 (1964) (statement of Mr. Callaghan).

${ }^{249}$ Callaghan, supra note 31 , at 214.
} 
the classical corporate income tax recommended by Kaldor in $1955 .{ }^{250}$ According to Callaghan, separating the corporate and individual income taxes would have the added benefits of simplifying the tax structure, ending certain abuses of the system, and permitting the separation of corporate and individual tax rates. ${ }^{251}$ Corporate income would thus be subject to tax at both the corporate level when earned and again at the shareholder level when distributed as a dividend. Unlike the U.S., where the shareholderlevel tax was paid by the shareholders themselves, companies would be directed to withhold and remit the shareholder-level tax when dividends were paid. ${ }^{252}$ While Callaghan conceded that this new system would subject company profits to double taxation, he noted that Parliament had long since abandoned the single tax concept when it introduced the profits tax. ${ }^{253}$

\footnotetext{
${ }^{250}$ See supra text accompanying note 242. Since Kaldor's recommendation for a classical corporate tax system in 1955, a series of writers had pushed the concept in subsequent years. See 712 PARL. DEB., H.C. (5th ser.) 51 (1965) (statement of Mr. Niall MacDermot) (citing "Taxes for Today," a 1958 pamphlet published by the Conservative Political Centre, "The Young Conservative, a 1963 pamphlet, and an article on Tory policy in the July 27, 1964 issue of the Daily Telegraph); DAUNTON, supra note 7, at 291 (Kaldor "continued to press for a return to differentiation in the party debates of the late 1950s and early 1960s.").

${ }^{251}$ See 701 PARL. DEB., H.C. ( $5^{\text {th }}$ ser.) 1041-42 (1964) (statement of Mr. Callaghan). The ability to impose separate rates at the corporate and individual levels was thought to permit government to target tax incentives as an aid to national planning of the economy. See DAUNTON, supra note 7, at 291-92.

An additional concern was that money was being invested overseas rather than in British industry. See 712 PARL. DEB., H.C. (5th ser.) 57 (1965) (statement of Mr. MacDermott). While this issue was heavily debated, some suspected it was not an original justification for the measure, but was only added as the balance of payments started to become a concern. See 713 PARL. DEB., H.C. $\left(5^{\text {th }}\right.$ ser.) 1828 (1965) (statement of Mr. Biffen) ("I regard this argument [that the position of overseas investment has necessitated the introduction of the Corporation Tax] with a great deal of suspicion, not least because, when the Chancellor first announced the Corporation Tax, last November, he made no reference whatsoever to the fact that it would be of some assistance to our overseas situation.").

${ }^{252}$ This was justified "[a]s a matter of administrative convenience." Shareholders who were exempt from tax or not subject to tax at the full standard rate were entitled to file a refund claim. See Callaghan, supra note 31 , at 214.

${ }^{253}$ See 710 PARL. DEB., H.C. ( $5^{\text {th }}$ ser.) 254 (1965) (statement of Mr. Callaghan) ("Hitherto any idea of reforming the Tax system by introducing a Corporation tax in this country has foundered because of the widely held view that to levy a separate tax on company profits which is distinct from, and additional to, the Income Tax levied on individuals would constitute "double taxation" of company profits. The Profits Tax already contradicts this argument."). Opponents countered that the differential profits tax only imposed a 15 percent burden while the proposed Corporation Tax would impose a double tax burden of between 35 and 40 percent. See 713 PARL. DeB., H.C. (5th ser.) 1724 (1965) (statement of Mr. Barber). As the Inland Revenue had itself concluded in 1959, "[a]1l the history and tradition behind our tax code
} 
Debate over the proposal centered at least in part around the claim that it would spur productive reinvestment of profits, although there was also dispute as to whether retentions would increase at all. ${ }^{254}$ Gresham Cooke argued that the concept was "oldfashioned." ${ }^{, 255} \mathrm{He}$ noted that "other countries are seeing that old established, undynamic companies can go on adding to their retentions year after year without any great benefit to themselves or their country. They can have a long series of profitless expansions." ${ }^{256}$ J. Grimond confirmed that this phenomenon was occurring in the U.K. as well. According to Grimond, "[s]ome big companies appear to be diversifying their activities because they have nothing else to do with the large funds which they acquire. Some companies should curtail their activities and distribute their reserves rather than retain money on which they do not earn as high a rate as is needed in the national interest."257 A recently published study by the economist Ian Little, which tentatively concluded that retained earnings as a result of the differential profits tax in the 1950s were inefficiently employed, ${ }^{258}$ was cited prominently in support of the Conservative opposition's arguments. ${ }^{259}$ Terrence Higgins summed up the disagreement over the corporation tax as lying between "whether we believe profits should be ploughed back into companies and taxes should encourage this, or whether we should encourage the distribution of profits

could be prayed in aid of this criticism." R.C. Whiting, Ideology and Reform in Labour's Tax Strategy, 1964-1970, 41 HIST. J. 1121, 1123 (1998) (quoting Board of Internal Revenue, A Corporation Tax, Public Record Office, Treasury Budget Papers T 171/508 (Dec. 30, 1959)).

${ }^{254}$ Some opponents argued that the "stickiness" of dividend rates meant that companies would pay the additional corporate tax out of money that would otherwise be available for "ploughing back" into the firm. See, e.g., 713 PARL. DEB., H.C. (5 ${ }^{\text {th }}$ ser.) 1879 (1965) (statement of Mr. Barber).

${ }^{255} \mathrm{Id}$. at 1000 (statement of Mr. Gresham Cooke).

${ }^{256} \mathrm{Id}$.

257712 PARL. DEB., H.C. (5th ser.) 94 (1965) (statement of Mr. J. Grimond).

${ }^{258}$ See I.M.D. Little, Higgledy-Piggledy Growth, 24 BuLl. OXFORD InST. OF STATISTICS 412 (1962).

${ }^{259}$ See 713 PARL. DEB., H.C. (5 ${ }^{\text {th }}$ ser.) 1885 (1965) (statement of Mr. Patrick Jenkin). 
and the operation of the capital market in such a way that capital is attracted into new uses by market forces."260 According to Higgins,

[w]e on this side believe strongly that it is better that the balance should be in favour of distribution rather than that there should be a very serious move in favour of ploughing back. If one ploughs back, it means that capital is retained by those companies which are already in existence. This in turn, means that there is less opportunity for new firms to obtain capital needed to expand and these firms are, indeed, the growth points of the economy. This is a fundamental difference between the two parties. ${ }^{261}$

Opponents concluded that companies were more efficient when they were subject to the scrutiny of the capital markets in order to obtain more funds. ${ }^{262}$

Proponents of the move to a classical corporate income tax argued that retentions were the most likely source of new investment in the British economy. ${ }^{263}$ According to the Financial Secretary to the Treasury, Niall MacDermott, evidence presented to the 1955 Royal Commission had established that "the amount of new money raised through the market is marginal in relation to the total investment. It is retentions that are responsible for far the greater part of capital investment in the private sector." ${ }^{264}$ The Chief Secretary to the Treasury, John Diamond, further substantiated such evidence, noting that only 9 percent of new investment came from cash raised through public issues of stock, while 65 percent came from retained earnings and the rest from borrowing. ${ }^{265}$ Diamond explained that " $[\mathrm{w}] \mathrm{e}$ are, therefore, framing a tax structure under which a

\footnotetext{
${ }^{260} 710$ PARL. DEB., H.C. $\left(5^{\text {th }}\right.$ ser.) 1051 (1965) (statement of Mr. Terrence Higgins).

${ }^{261} I d$.

${ }^{262}$ Id. (citing Little's study)

${ }^{263}$ See 712 PARL. DeB. H.C. (5th ser.) 53 (1965) (statement of Mr. Niall MacDermot) ("it is from retentions that the great weight of money comes for industrial and commercial expansion."); id. at 130 (statement of Mr. A.E.P. Duffy) ("Many hon. Members recognise now that the bulk of firms get the bulk of their additional capital for necessary growth out of retained profits.").

${ }^{264}$ Id. at 52-53 (citing evidence offered by the Issuing Houses Committee). See Callaghan, supra note 31, at 215 ("in the United Kingdom it does seem that the main source of finance for industrial investment is nowadays 'plough back."”).

${ }^{265} 713$ PARL. DEB., H.C. (5 ${ }^{\text {th }}$ ser.) 1835-36 (1965) (statement of John Diamond).
} 
business man will, out of his realised profits, have 50 per cent. more cash available for investment and plough-back than he has under the present system"266 While he conceded that "[o]ne cannot make individuals who are inefficient efficient" simply by providing additional funds, Diamond suggested that the bill would "encourage them towards efficiency and give them the tools to achieve it." ${ }^{267}$

As one would expect from American firms with professional managers and dispersed owners, some larger British companies appeared to support this conversion to a double tax system. ${ }^{268}$ According to The Economist, "a good few company chairman" applauded the proposed adoption of a tax disincentive to distributions because they saw "dividends as an extravagance and retained profits as the real source of expansion."269 Malcolm Crawford explained, "companies in industry and commerce here prefer financing from retentions, treating external finance as a residual source, for meeting peaks in investment programmes, or when forced into the market by a credit squeeze."270 As evidence of the residual nature of capital market financing, Crawford noted that large dividend distributions were not matched by large public offerings of additional stock. ${ }^{271}$ There was some suggestion that stockholder pressure would counterbalance business'

\footnotetext{
${ }^{266} I d$. at 1833 .

${ }^{267} \mathrm{Id}$.

${ }^{268}$ While individual companies may have preferred the Labour proposal, the Federation of British Industries appears to have lined up with the Opposition in favoring a dividend-friendly system. See DAUNTON, supra note 7, at 320. It is not clear why they took that approach, although it may have represented either an extension of their opposition to any entity-level tax, whether a profits tax or a corporation tax, that characterized their opposition in the 1950s, see supra text accompanying notes 304-07, or a concern for the instability that the new measures would bring. See STEPHEN BLANK, INDUSTRY AND GOVERNMENT IN BRITAIN: THE FEDERATION OF BRITISH INDUSTRIES IN POLITICS, 1945-65 224 (1973). ${ }^{269}$ Labour's Tax Imprint, THE ECONOMIST 738 (1964).

${ }^{270}$ Malcolm Crawford, The 1965 Reforms in the British Tax System, Moorgate AND WaLl STREeT, Aut. 1965 , at $38,42$.

${ }^{271} I d$.
} 
temptation to use the new tax as justification to increase retained earnings, ${ }^{272}$ but others thought that the tax would "widen the gulf between modern and contemporary industrial management and the shareholders" so as to increase the power of the former to ignore the demands of the latter. ${ }^{273}$

Callaghan's proposal for a classical corporate income tax was adopted in $1965,{ }^{274}$ but it was the source of significant controversy almost from the beginning. One commentator warned, rather caustically, "it is the height of folly" to simultaneously attempt to effect the "euthanasia of the shareholder" while "pay[ing] lip service to the merits of private enterprise." ${ }^{275}$ Perhaps the most stinging blows came from reports that the introduction of the classical corporate income tax was having little effect on firm dividend policies or on economic growth. ${ }^{276}$

\footnotetext{
272 See 712 PARL. DEB., H.C. (5th ser.) 131-32 (1965) (statement of Mr. Duffy) ("We know, and some hon. Members opposite know better than we do, how many directors are so concerned for their standing in the markets that they will be tempted to cut back retentions to preserve dividends.").

273713 PARL. DEB., H.C. ( $5^{\text {th }}$ ser.) 1829 (1965) (statement of Mr. Biffen).

${ }^{274}$ Finance Act of 1965, §§ 46-89. In another significant development, Parliament imposed a tax on longterm capital gains for the first time (short-term capital gains were subject to tax under the Finance Act of 1962). This was ironic considering the tax on capital gains would likely reduce incentives for investment. One way to reconcile these two seemingly inconsistent prongs of Labour's tax strategy is by concluding that the Party wanted to encourage investment by business managers rather than by individuals. See Crawford, supra note 270, at 44. Supporters also pointed out that it was possible to devise a capital gains tax that would not inhibit investment, but would still achieve its other goals. See id. at 50. A more pragmatic way to reconcile the corporate tax and capital gains tax is that since companies would presumably increase their retained earnings, share values would rise and corporations would extract their gains through sales of stock rather than dividends. Those sales of stock, which were previously tax-free, would now be taxed. Thus, the capital gains tax served as a substitute for the tax revenue from dividends. See DAUnTON, supra note 7, at 318-19.

${ }^{275}$ A.R. Hersic, Taxes 1964-66: An Interim Appraisal, 1966 BRIT. TAX REV. 365, 373.

${ }^{276}$ See R.J. Brinston \& C.R. Tomkins, The Impact of the Introduction of Corporation Tax Upon the Dividend Policies of United Kingdom Companies, 80 ECON. J. 617, 627 (1970) (noting, in a study of 837 U.K. firms, that retained earnings was typically a residual item after dividend payouts were met and therefore "[i]t would appear that companies can be encouraged to retain profits only by a fiscal policy which gives them increased earnings."); DAUNTON, supra note 7, at 299 ("The Callaghan-Kaldor reforms were disappointing, for they produced little revenue and did not stimulate economic growth to any discernible extent.").
} 
Once the Conservatives regained office in 1970, they set about dismantling the corporation tax. ${ }^{277}$ In his March 30, 1971 Budget Statement, Anthony Barber, the new Chancellor of the Exchequer, announced the government's intention to replace the corporation tax and "the substantial discrimination which it entails in favour of retained as opposed to distributed profits." ${ }^{278}$ Rather than doing so immediately, though, Barber chose to publish his office's proposals in a "Green Paper" that would be made available for further consideration. ${ }^{279}$ In the Green Paper, Barber advocated a two-rate system much like the German approach in which distributed profits would be subject to tax at a lower rate than undistributed profits, but he also indicated willingness to consider a shareholder imputation system. ${ }^{280}$ A Select Committee on Corporation Tax was formed by the House of Commons to consider the proposals contained in the Green Paper. In its report, ${ }^{281}$ the Select Committee recommended adoption of the shareholder imputation system in large part because of the concerns surrounding overseas income earned by UK companies. $^{282}$

On April 6, 1973, Parliament adopted the Select Committee's recommendations and thus ended the U.K.'s short experiment with a classical corporate income tax. ${ }^{283}$ In many respects, however, this new system was similar to the classical corporate tax that it

\footnotetext{
${ }^{277}$ DAUNTON, supra note 7 , at 326.

278814 PARL. DEB., H.C. (5th ser.) 1383 (1971) (statement of Chancellor of the Exchequer, Anthony Barber).

${ }^{279}$ Id.; Reform of the Corporation Tax, Cmnd. 4630 (1971). Part of the justification for delay was to permit possible coordination with the reform of corporation taxes among countries in the European Economic Community. Id. at 2.

${ }^{280} I d$.

${ }^{281}$ See Report from the Select Committee on Corporation Tax, Session 1970-71 (Oct. 20, 1971) ("Select Committee Report").

${ }^{282}$ Id. at xiii, para. 24 ("The arguments in favour of the imputation system spring basically from this country's position as an international trader and investor. All whom Your Committee questioned agreed that the imputation system was preferable to the two-rate system as a basis for the renegotiation of double taxation agreements (which will be necessary whatever system is finally adopted.))."

${ }^{283}$ Finance Act of 1972.
} 
replaced. ${ }^{284}$ Corporations were subject to tax on their income and dividends were not deductible from corporate income for purposes of calculating tax. Shareholders were also subject to income tax on dividends received. It also resembled the system in place prior to 1965 , though, in that Parliament relieved double taxation of corporate income by providing shareholders a credit to relieve some of the tax paid at the corporate level. Much like the modern payroll withholding system, the dividend was grossed up to reflect both the cash paid and the credit, with the credit calculated so as to equal the income tax liability on the grossed-up dividend at the basic rate. This meant that lower rate taxpayers had no further liability or were eligible for a refund if their rate was less than the base rate, such as with tax-exempt pension funds, while higher rate taxpayers were subject to tax on the additional amount. ${ }^{285}$

The most significant innovation from both the pre and post-1965 systems was the adoption of an Advance Corporation Tax ("ACT"). Under this provision, a corporation had to pay a tax with respect to any dividends paid, irrespective of whether it actually had any tax liability. ${ }^{286}$ The ACT then could be offset against the corporation's actual tax due. ${ }^{287}$ If the actual tax due was low relative to a company's dividend payments, such as when it has a bad year or when much of its profits are generated and taxed overseas, then the company receives surplus ACT credits that could be carried backward or forward over a period of years. In effect, the ACT acted as a prepayment for the corporation's actual tax liability. This responded to one of the concerns with the pre 1965 shareholder

\footnotetext{
${ }^{284}$ See Andreas Tontsch, Corporation Tax Systems and Fiscal Neutrality: The UK and German Systems and Recent Changes, 30 INTERTAX 171, 175 (2002).

${ }^{285}$ See id. at 175.

${ }^{286}$ See Malcolm Gammie, UK Imputation, Past, Present and Future, BuLl. FOR InT'L FISCAL DOCUMENTATION 429 (Oct. 1998). ${ }^{287}$ Id.
} 
imputation system that related to the potential for the tax credit to exceed the amount of the corporation's actual tax liability.

$$
\text { 3. } 1997
$$

In the mid-1990s, the U.K. once again became concerned with dividends and firm investment. A 1995 study published by the Institute for Fiscal Studies announced that there had been a dramatic rise in the percentage of profits paid out as dividends during the previous decade. ${ }^{288}$ In a press release accompanying this announcement, the IFS noted that "[t]he dividend payout ratio . . . is higher in the UK than in any other major economy. There is a danger that these high dividend payouts are having an adverse effect on business investment. ${ }^{289}$ Other studies reached similar conclusions regarding the dangers of increased dividends. ${ }^{290}$ By 1997, with dividends continuing to rise and Labour poised to retake power for the first time in 18 years, ${ }^{291}$ the corporate tax system appeared to be headed for another revision. ${ }^{292}$

In his July 2, 1997 Budget Message, Chancellor Gorden Brown noted that "[s]ince 1980 the UK has invested a lower share of GDP than most other industrialised countries .... For every $£ 100$ invested per worker in the UK, Germany has invested over

\footnotetext{
${ }^{288}$ See Bond et al., supra note 196, at 3.

${ }^{289}$ See Press Release, Company Dividends and Taxes in the UK (Aug. 31, 1995), available at http://www.ifs.org.uk/press/fsdivs.shtml, last visited on Aug. 21, 2002.

${ }^{290}$ See David Wighton, Labour Tax Shake-Up Likely to Highlight Investment, FIN. TIMES (London), Apr. 1, 1997, at 10 (citing a study by the Commission on Public Policy and British Business).

${ }^{291}$ See Malcolm Gammie, The End of Imputation: Changes in UK Dividend Taxation, 25 INTERTAX 333 (1997).

${ }^{292}$ See Barry Riley, Reaping Tory Dividends, Fin. TIMES (London), April 19, 1997 at 1; Robert Peston, Brown May Scrap Dividend Credit, Fin. Times (London), June 16, 1997, at 1; Jim Kelly, Under Fire for "Victimless" Tax Increase: Brown May Defy Critics Over Dividend Credits, FIN. TIMES (London), June 16, 1997, at 11; The Lex Column, Taxing Times, Fin. Times (London), June 16, 1997, at 22; Philip Coggan, Not the Easy Option, Fin. TIMES (London), June 21, 1997, at 8.
} 
$£ 140$, the US and France around $£ 150$, and Japan over $£ 160$ per worker." ${ }^{293}$ Brown announced that while the Labour Party had been studying the system for the past two years with an eye toward redressing this investment deficiency, "this point in the recovery is ... the right time to make changes in corporation tax to encourage more long term investment. ${ }^{294}$ The bill for reform was passed in less than a month. ${ }^{295}$

Labour revised the corporate tax in two phases. Effective immediately, it reduced the corporate tax rate by two percentage points and abolished the refundable shareholder dividend tax credit for tax-exempt institutional investors such as pension funds. ${ }^{296}$ Prior to this latter reform, a dividend of 80 to a tax-exempt investor was worth 100 because of the refund of the $20 \%$ tax credit then provided for under the partial imputation system. ${ }^{297}$ As Brown emphasized in his Budget Message, subsidizing dividend payments to pension funds, which owned more than half of all public stock at the time, ${ }^{298}$ "encourage[d] companies to pay out dividends rather than reinvest their profits." ${ }^{299}$ The parallel with Labour's 1965 reforms and the Kaldor's Minority Report to the 1955 Royal Commission was not lost on commentators, ${ }^{300}$ although this time it did not have the support of business trade groups. ${ }^{301}$

\footnotetext{
${ }^{293}$ The Chancellor's 1997 Budget Speech at para. 59, available at http://archive.treasury.gov.uk/pub/html/budget97/chxstat2.html (last visited Feb. 5, 2003) ("1997 Budget Message").

${ }^{294} I d$. at paras. 60,62 .

${ }^{295}$ See Gammie, supra note 291, at 333.

${ }^{296}$ Finance (No. 2) Act 1997, § 19.

${ }^{297}$ See Gammie, supra note 291, at 335.

${ }^{298} I d$.

2991997 Budget Message, supra note 293, at para. 72.

${ }^{300}$ See Graham Searjeant, Dividend Grab is Economic Nonsense, TIMES (London), July 24, 1997 ("The agenda is an old Labour one. It dates back to the revolution in company tax made in Lord Callaghan's comparable first Labour Budget of 1965 . . . Essentially, Mr. Brown aims to reinstate the reforms proposed by the late old Labour Lord Kaldor a generation ago.").

${ }^{301}$ See Brown's First Budget -- Business and Market Reaction, Fin. TIMES (London), July 3, 1997, at 3 (Mr. Adair Turner, director general of the Confederation of British Industries, said . . . one measure -- the radical
} 
In the second phase of the revision to the corporate tax, effective April 6, 1999, the elimination of the refundable shareholder tax credit for tax-exempt investors was extended to taxable shareholders. ${ }^{302}$ The shareholder tax credit on dividends was also reduced from 20 percent to 10 percent. ${ }^{303}$ In an additional reform enacted in 1998, but implemented at the same time as the second phase of the 1997 reform, the ACT was abolished altogether. ${ }^{304}$ The combined effect of the 1997 and 1999 reforms has been to eliminate the U.K.'s shareholder imputation system and push it ever closer to a classical double tax. ${ }^{305}$

\section{Conclusion}

The dividend divide appears to have had a significant influence on the direction of corporate tax reform in the U.S. and U.K during the past century. A consistent theme in the U.S. has been that dividends are too low and in the U.K. that dividends are too high. During periods of heightened concern about these trends, the U.S. and British corporate income taxes have been reformed accordingly. Thus, the U.S. adopted a more integrationist approach to corporate taxation in both the New Deal and in the latest round of President Bush's tax cuts in part because dividends were perceived to be too low.

Similarly, on four separate occasions in the last half-century, the U.K. has adopted a more

change to the corporation tax regime -- we do not support ... The CBI is disappointed that such a major change in corporate taxation was introduced without proper prior consultation.").

${ }^{302}$ Finance (No. 2) Act of 1997, § 30 .

${ }^{303} \mathrm{Id}$.

${ }^{304}$ Finance Act of $1998, \S 31$.

${ }^{305}$ See Casson, supra note 32, at 493 ("the abolition of advance corporation tax (ACT) with effect from April 1999 will mark the end of the imputation system of corporation tax introduced a quarter of a century ago."); Avi-Yonah, supra note 6, at 1599 (noting that "[i]ntegration has been cut back severely in ... the U.K."); Tontsch, supra note 284, at 178 ("With the abolition of ACT, the only link between the corporation tax paid by the company and the tax credit for the shareholder has been eliminated. The tax credit is 
classical approach to corporate taxation in part because of the perception that dividends were too high.

There are several potential implications from the existence of a dividend divide in Anglo-American corporate taxation. First, it serves as a cautionary note for those seeking to unify the tax treatment of corporate income in the U.S. and U.K. without considering the underlying difference in firm dividend policy and the perceptions of its importance in the two countries. It may also help to provide a starting point for further investigations into why the U.S. corporate income tax has diverged from the corporate income taxes of other countries, such as France, Germany, Japan, and Italy, where similar reforms of the corporate income tax are either being considered or recently have been implemented. ${ }^{306}$

More broadly, it suggests that corporate tax policy may be dictated more by the realities of corporate behavior than the theories underlying the nature of the corporation as a separate taxable actor. This is contrary both to the traditional assumptions regarding the divergence of the U.S. and British systems and to some recent views regarding the normative rationale for the corporate tax. ${ }^{307}$ Debunking this entity theory perspective may aid in the movement toward a more realistic approach to corporate taxation.

Finally, and perhaps most importantly, the dividend divide provides a counterstory to the traditional argument that the design of a corporate income tax system exerts a

granted regardless of whether any corporation tax has been paid on the profit at all. Consequently, it cannot be said that corporation tax is imputed to the shareholder.").

${ }^{306}$ See Avi-Yonah, supra note 6, at 1600 . An alternative view is that each country is converging toward a system of partial integration, although this depends upon one's prediction about the end point for each system. They may end up passing each other like ships in the night.

${ }^{307}$ See Reuven Avi-Yonah, Corporations, Society, and the State: A Defense of the Corporate Tax (unpublished manuscript, 2004) (suggesting a real entity theory of the corporation, although also arguing that this justifies the use of the corporate tax to regulate corporate behavior, which is consistent with the premises of the dividend divide). 
significant effect on corporate behavior. ${ }^{308}$ While it is true that the corporate income tax can distort decision-makingand thereby introduce inefficiencies to the economy, too little has been said about the other side of the equation. The corporate income tax is often structured as a response to corporate behavior that is considered improper either from a tax policy perspective (because it erodes the tax base) or from a corporate policy perspective (because it harms corporate shareholders, stakeholders or th economy generally). It may be that tax is an inappropriate tool to address the latter concern, ${ }^{309}$ but it is well to recognize that the inefficiency may be an endogenous inefficiency that the corporate tax system is itself trying to correct or has been manipulated by corporate managers to cover. In effect, the corporate tax system is not merely the source of several inefficiencies, but may be a part of the multitude of factors that reflect the inefficiencies in our corporate economy.

\footnotetext{
${ }^{308}$ See, e.g., R. Glenn Hubbard, Corporate Tax Integration: A View From the Treasury Department, 7 J. ECON. PERSP. 115, 117-18 (1993) ("The classical corporate income tax distorts three economic and financial decisions. Namely, whether to: (1) invest in noncorporate rather than corporate form; (2) finance investments with debt rather than equity; and (3) retain rather than distribute earnings.").

${ }^{309}$ See Bank, Norms, supra note 110 (distinguishing between corporate governance-oriented tax provisions that fail and those that survive).
} 